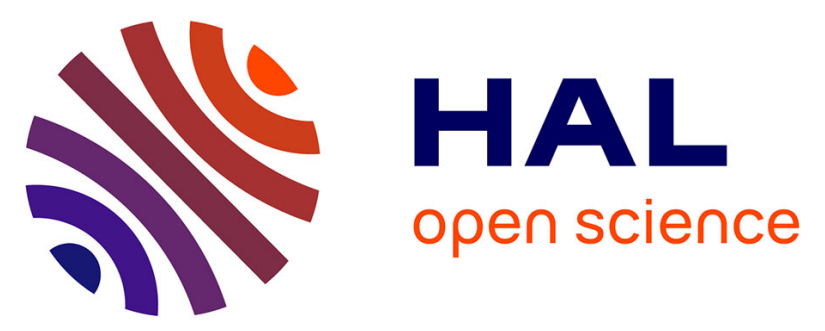

\title{
Synthesis, crystal structure and antibacterial studies of 2,4,6-trimetoxybenzaldehyde based dihydropyrimidine derivatives
}

\author{
A. E. Huseynzada, C. Jelsch, H. N. Akhundzada, S. Soudani, C. Ben Nasr, F. \\ Doria, U. A. Hasanova, M. Freccero, Z. Gakhramanova, K. Ganbarov, et al.
}

\section{To cite this version:}

A. E. Huseynzada, C. Jelsch, H. N. Akhundzada, S. Soudani, C. Ben Nasr, et al.. Synthesis, crystal structure and antibacterial studies of 2,4,6-trimetoxybenzaldehyde based dihydropyrimidine derivatives. Journal of Molecular Structure, 2021, 1241, pp.130678. 10.1016/j.molstruc.2021.130678 . hal03231844

\section{HAL Id: hal-03231844 \\ https://hal.science/hal-03231844}

Submitted on 21 May 2021

HAL is a multi-disciplinary open access archive for the deposit and dissemination of scientific research documents, whether they are published or not. The documents may come from teaching and research institutions in France or abroad, or from public or private research centers.
L'archive ouverte pluridisciplinaire HAL, est destinée au dépôt et à la diffusion de documents scientifiques de niveau recherche, publiés ou non, émanant des établissements d'enseignement et de recherche français ou étrangers, des laboratoires publics ou privés. 


\title{
Published in Journal of Molecular Structure, 2021, 130678, ISSN 0022-2860, https://doi.org/10.1016/j.molstruc.2021.130678.
}

Synthesis, crystal structure and antibacterial studies of 2,4,6-trimetoxybenzaldehyde based dihydropyrimidine derivatives

\author{
A.E. Huseynzada ${ }^{1 *}$, C. Jelsch ${ }^{2}$, H.N. Akhundzada ${ }^{1,3}$, S. Soudani ${ }^{4}$, C. Ben Nasr ${ }^{4}$, \\ F. Doria ${ }^{5}$, U.A. Hasanova ${ }^{1}$, M. Freccero ${ }^{5}$, Z. Gakhramanova ${ }^{6}$, K. Ganbarov ${ }^{7}$, B. Najafov ${ }^{8}$ \\ ${ }^{1}$ Baku State University, ICRL, Z. Khalilov 23, Baku, AZ 1148, Azerbaijan \\ ${ }^{2}$ Université de Lorraine, CNRS, CRM2, F-54000 Nancy, France \\ ${ }^{3}$ Institute of Radiation Problems of ANAS, B. Vahabzada 9, Baku, AZ 1143, Azerbaijan \\ ${ }^{4}$ Laboratoire de Chimie des Matériaux, Université de Carthage, Faculté des Sciences de Bizerte, \\ 7021, Zarzouna, Tunisia \\ ${ }^{5}$ Universita di Pavia, V.le Taramelli 10, 27100 Pavia, Italy \\ ${ }^{6}$ Chemical Sensors and Reagents Laboratory, Azerbaijan State Oil and Industry University, \\ Baku, Azerbaijan \\ ${ }^{7}$ Baku State University, Laboratory of Microbiology and Virology, Z. Khalilov 23, Baku, AZ \\ 1148, Azerbaijan \\ ${ }^{8}$ Ostim Technical University, Ankara, Turkey \\ *corresponding author e-mail: alakbar.huseynzada1117@gmail.com
}

\begin{abstract}
We report herein the synthesis of new derivatives of dihydropyrimidine on the basis of 2,4,6-trimetoxybenzaldehyde, which was further regioselectively oxidized in the presence of cerium ammonium nitrate (CAN) with the formation of 5-acetyl-6-methyl-4-(2,4,6trimethoxyphenyl)pyrimidin-2(1H)-one. The structures of both novel compounds were investigated by NMR, mass spectroscopy methods. The structure of the dihydropyrimidine compound 4 was also investigated by X-ray single crystal diffraction method. In order to understand the molecular interactions in its crystal packing, the Hirshfeld surface and contacts enrichment analyses were performed. Biological activities of the synthesized compounds were studied against gram-negative $A$. baumanii, E. coli, $P$. aeruginosa and $K$. pneumoniae and grampositive $S$. aureus bacteria.
\end{abstract}

Key words: Biginelli reaction, pyrimidine, cerium ammonium nitrate, Hirshfeld surface analysis, crystal structure, antibacterial activity. 


\section{Introduction}

Biginelli reaction as a typical representative of one-pot multicomponent reactions is an extremely potent synthetic strategy and highly flexible tool for the design and construction of dihydropyrimidines - a unique class of heterocyclic compounds with two nitrogen atoms in the cycle $[1,2]$. The potency of this reaction is caused by high complexity and a large diversity of the product despite using simple starting materials such as aldehyde, urea derivative and methylene active compound. The evidence of the widespread interest of the scientific community to Biginelli reaction is the numerous research articles as well as reviews published so far on this topic, which in turn led to dihydropyrimidines being known in medicine and brought them enormous fame. The reason of such reputation is caused by the broad spectrum of biological activities of dihydropyrimidines [4-6]. According to the umpteen investigations, these compounds demonstrate anti-leishmanial [7], antitumor [8-13], antiviral [14, 15], antifungal [16], antiproliferative [17, 18], antibacterial [19-21], anti-inflammatory [22-24], anti-hypertensive [25-27], antiepileptic [28], anti-HIV [29], antidiabetic [30, 31], anti-malarial [32], mPGES-1 inhibitors [33], antitubercular [34], miscellaneous [35-37] activities, as well as calcium [38] and potassium channels [39-41] and $\alpha_{1 \mathrm{a}}$ adrenergic antagonists [42]. However, the mentioned broad spectrum of activities is not an application limit of dihydropyrimidines in medicine. A class of compounds can show extremely good results against various microbes, but because of a number of factors (toxicity, solubility, absorbability and so on) it cannot be a drug [43-45]. A uniqueness of dihydropyrimidines is that different drugs were synthesized on the basis of them (Fig. 1). Compounds which found their application in medicine include batzelladine A and B against HIV [29], (S)-monastrol, (S)enastron, mon-97, (R)-fluorastrol against cancer [8-13], terazosin for treating of benign prostatic hyperplasia (prostate enlargement) and high blood pressure [36].

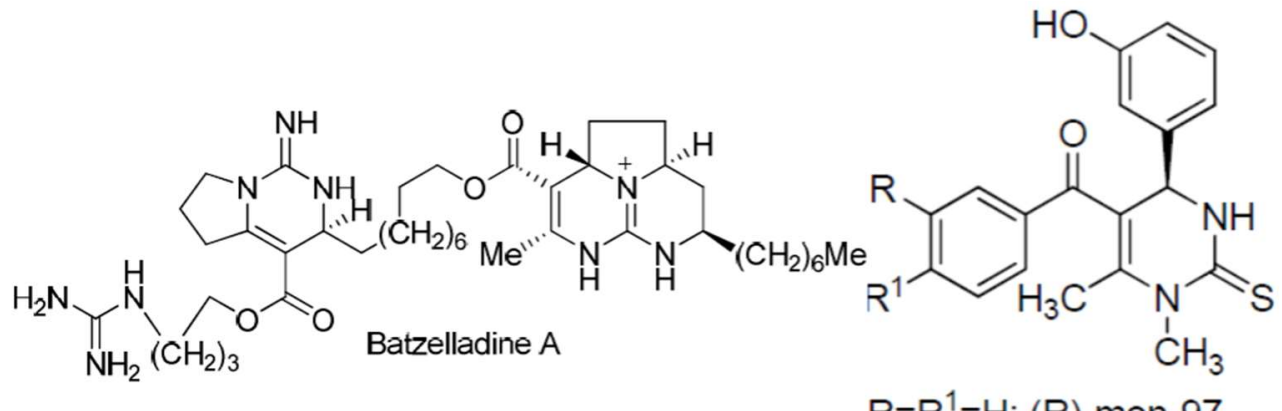

$\mathrm{R}=\mathrm{R}^{1}=\mathrm{H}:(\mathrm{R})-\mathrm{mon}-97$.

$R=R^{1}=F:(R)-$ fluorastrol.<smiles>CCOC(=O)C1=C(C)NC(=S)N[C@H]1c1cccc(O)c1</smiles>

(S)-monastrol

Figure 1. Acclaimed drugs on the basis of dihydropyrimidines

On the other hand, various procedures have been developed in order to modify the structure of dihydropyrimidines allowing introducing various pharmacophoric groups in their structure [36, 46-48]. One of such type modifications is the regioselective oxidation of dihydropyrimidine ring. This leads to the disappearing of one amine group, leaving another amine group as the only nucleophilic center that in turn impact on selectivity of the targeted $\mathrm{N}$-modified product. Another advantage of dihydropyrimidine ring oxidation is its solubility. The point is that dihydropyrimidines, on the basis of aromatic aldehydes, are mostly soluble only in high polar 
solvents such as methanol, ethanol, acetonitrile and DMSO. Some of them are only soluble just in DMSO, whereas oxidized products are also soluble in solvents with low polarity, such as chloroform, dichloromethane, ethyl acetate, which in turn expands their application area. Furthermore, in some cases, oxidized dihydropyrimidines are more biologically active than initial dihydropyrimidines [49-52].

Concerning the biological activity of dihydropyrimidine core, a new dihydropyrimidine, compound 4, was synthesized by Biginelli reaction in microwave condition in the presence of copper triflate on the basis of 2,4,6-trimethoxybenzaldehyde. Taking into account the above mentioned perspectives of dihydropyrimidine ring oxidation reaction, the obtained dihydropyrimidine $\mathbf{4}$ was regioselectively oxidized with the formation of a novel pyrimidine $\mathbf{5}$. As crystals of the dihydropyrimidine 4 were obtained, its structure was investigated by X-ray single crystal diffraction. In addition, the Hirshfeld surface and contacts enrichments analysis was done to quantify the molecular interactions and understand their importance in the crystal packing. Due to the fact that dihydropyrimidines demonstrate a wide spectrum of biological activities, the antibacterial activity of novel synthesized compounds $\mathbf{4}$ and $\mathbf{5}$ was analyzed against A.baumanii, E.coli, P.aeruginosa, K.pneumoniae and S.aureus bacteria and promising results were obtained.

\section{Materials and methods}

\subsection{General Information}

All the solvents and reagents were purchased from commercial suppliers and were of analytical grade and used without further purification. The control of the reactions progress and the determination of the synthesized compounds purity were done by thin layer chromatography (TLC) on Merck silica gel plates (60 F254 aluminium sheets) which were visualized under UV light. Melting points were recorded in open capillary tubes on a Buchi B-540 apparatus and were uncorrected. Elemental analysis was performed on the Carlo Erba 1108 analyzer.

\subsection{Experimental synthesis procedure}

\section{3}

2.2.1 Synthesis of 5-acetyl-6-methyl-4-(2,4,6-trimethoxyphenyl)-3,4-dihydropyrimidin-2(1H)-one (4) by Biginelli reaction

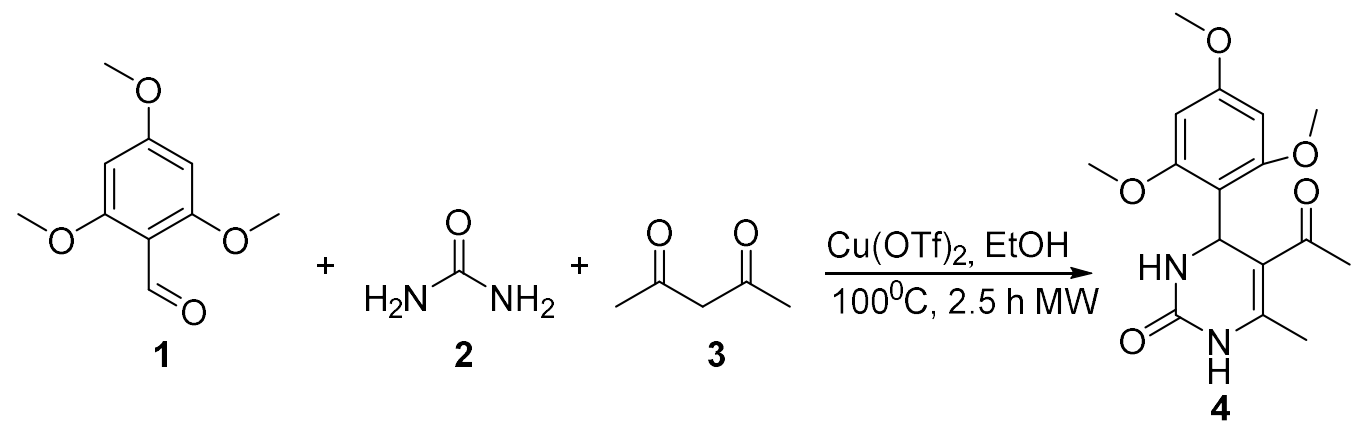

Scheme 1. Synthesis of targeted dihydropyrimidine 4. 
$0.5 \mathrm{mmol}$ of 2,4,6-trimethoxybenzaldehyde, $0.75 \mathrm{mmol}(45 \mathrm{mg})$ of urea and $0.027 \mathrm{mmol}$ $(10 \mathrm{mg})$ of copper-triflate $\mathrm{Cu}(\mathrm{OTf})_{2}$ were added to a microwave vial with a magnetic stirrer and dissolved in $1 \mathrm{ml}$ of ethanol (Scheme 1). Subsequently, $0.49 \mathrm{mmol}(50 \mu \mathrm{l})$ of acetylacetone was added to a vial, which was sealed and irradiated at $100^{\circ} \mathrm{C}$ in a microwave reactor for $2.5 \mathrm{~h}$ at a maximum power of $200 \mathrm{~W}$ (CEM Discover ${ }^{\mathrm{TM}}$ System). At the end of reaction time, the precipitate was formed, filtered, washed with distilled water and dried. Single crystals of compound (4) were obtained by crystallization in methanol. Yield $80 \%$. M.p. $249-250^{\circ} \mathrm{C} .{ }^{1} \mathbf{H}$ NMR spectrum: $\left(\mathrm{DMSO}_{6}, \delta, \mathrm{ppm}\right), 1.91 \mathrm{~s}\left(3 \mathrm{H}, \mathrm{CH}_{3}\right), 2.11 \mathrm{~s}\left(3 \mathrm{H}, \mathrm{CH}_{3}\right), 3.72 \mathrm{~s}\left(6 \mathrm{H}, 2 \mathrm{OCH}_{3}\right), 3.76 \mathrm{~s}\left(3 \mathrm{H}, \mathrm{OCH}_{3}\right)$, $5.79 \mathrm{~s}(1 \mathrm{H}, \mathrm{CH}), 6.22 \mathrm{~s}\left(2 \mathrm{H}, 2 \mathrm{C}_{\mathrm{Ar}} \mathrm{H}\right), 7.03 \mathrm{~s}(1 \mathrm{H}, \mathrm{NH}), 8.95 \mathrm{~s}(1 \mathrm{H}, \mathrm{NH}) .{ }^{13} \mathbf{C}$ NMR spectrum: $\left(\mathrm{DMSO}_{\mathrm{d}} \mathrm{d}, \delta, \mathrm{ppm}\right), 18.8\left(\mathrm{CH}_{3}\right), 28.9\left(\mathrm{CH}_{3}\right), 45.78(\mathrm{CH}), 55.19\left(\mathrm{OCH}_{3}\right), 55.74\left(2 \mathrm{OCH}_{3}\right), 91.26$ $\left(2 \mathrm{C}_{\mathrm{Ar}} \mathrm{H}\right), 105.91(\mathrm{C}), 113.22(\mathrm{C}), 146.9\left(\mathrm{C}_{\mathrm{Ar}}\right), 151.76\left(\mathrm{C}_{\mathrm{Ar}}\right), 158.78\left(2 \mathrm{C}_{\mathrm{Ar}}\right), 160.3(\mathrm{CO}), 195.09$ (CO). HRMS (ESI-MS): $343.17\left[\mathrm{M}^{+}+\mathrm{Na}^{+}\right]$. Elemental analysis calcd. for $\mathrm{C}_{16} \mathrm{H}_{20} \mathrm{~N}_{2} \mathrm{O}_{5}, \%$ : C, 59.99; H, 6.29; N, 8.74. Found, \%: C, 59.94; H, 6.37; N, 8.79. This compound can also be obtained by the following procedure. To a solution of 2,3 $\mathrm{mmol}(0,45 \mathrm{gr})$ of 2,4,6-trimetoxybenzaldehyde in $30 \mathrm{ml}$ of ethanol were added $10 \mathrm{mmol}(0.6 \mathrm{gr})$ of urea, $9.75 \mathrm{mmol}(1 \mathrm{ml})$ of acetylacetone and 8 $\mathrm{ml}$ of acetic acid. The reaction mixture was refluxed for $10 \mathrm{~h}$. At the end of reaction time, the mixture was cooled with ice and precipitate was formed, which was filtered, washed with distilled water and dried. Yield 58\%.

\subsubsection{Synthesis of 5-acetyl-6-methyl-4-(2,4,6-trimethoxyphenyl)pyrimidin-2(1H)-one} (5) by regioselective oxidation in the presence of CAN

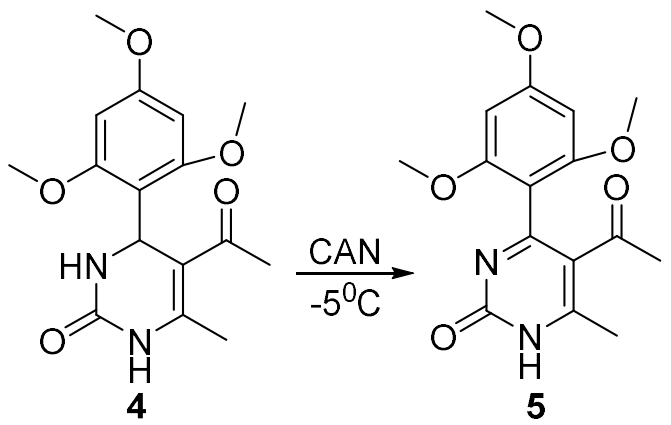

Scheme 2. Synthesis of pyrimidine 5 in the presence of CAN.

$0.30 \mathrm{mmol}$ of dihydropyrimidine 4 was dissolved in a solvent mixture consisting of $4 \mathrm{ml}$ DMSO and $4 \mathrm{ml}$ acetone. To this solution, $2 \mathrm{mmol}$ of sodium bicarbonate $\left(\mathrm{NaHCO}_{3}\right)$ was added. The temperature of the reaction mixture was decreased to $-5^{\circ} \mathrm{C}$. Then, $1.2 \mathrm{mmol}$ of CAN was dissolved in $2 \mathrm{ml}$ of water and added to the solution of dihydropyrimidine under argon (Ar) atmosphere (the color changed from orange to a pale yellow). The reaction mixture was stirred 1 hour at $-5^{\circ} \mathrm{C}$ and 20 hours at room temperature. At the end of reaction time, the reaction mixture was decanted with chloroform. Subsequently, the organic layer was washed with brine and dried over anhydrous sodium sulphate $\left(\mathrm{Na}_{2} \mathrm{SO}_{4}\right)$. Removing of chloroform gave a precipitate, which further purification with the Biotage Isolera One Flash Chromatography System (ethyl acetatemethanol: 9:1) allowed obtaining of pure oxidized dihydropyrimidine 5. Yield 36.4 \%. M.p. 265 - 
$266^{\circ} \mathrm{C} .{ }^{1} \mathbf{H}$ NMR spectrum: $\left(\mathrm{CDCl}_{3}, \delta, \mathrm{ppm}\right), 1.95 \mathrm{~s}\left(3 \mathrm{H}, \mathrm{CH}_{3}\right), 2.54 \mathrm{~s}\left(3 \mathrm{H}, \mathrm{CH}_{3}\right), 3.75 \mathrm{~s}(6 \mathrm{H}$, $\left.2 \mathrm{OCH}_{3}\right), 3.87 \mathrm{~s}\left(3 \mathrm{H}, \mathrm{OCH}_{3}\right), 6.16 \mathrm{~s}\left(2 \mathrm{H}, 2 \mathrm{C}_{\mathrm{Ar}} \mathrm{H}\right) .{ }^{13} \mathbf{C}$ NMR spectrum: $\left(\mathrm{CDCl}_{3}, \delta, \mathrm{ppm}\right), 23.28$ $\left(\mathrm{CH}_{3}\right), 30.05\left(\mathrm{CH}_{3}\right), 55.41\left(\mathrm{OCH}_{3}\right), 55.7\left(2 \mathrm{OCH}_{3}\right), 90.82\left(2 \mathrm{C}_{\mathrm{Ar}} \mathrm{H}\right), 102.9(\mathrm{C}), 120.84(\mathrm{C}), 156.85$ $\left(\mathrm{C}_{\mathrm{Ar}}\right), 158.56\left(2 \mathrm{C}_{\mathrm{Ar}}\right), 164.29(\mathrm{CO}), 171.17(\mathrm{C}), 171.34\left(\mathrm{C}_{\mathrm{Ar}}\right), 198.7$ (CO). HRMS (ESI-MS): $319.17\left[\mathrm{M}^{+}+\mathrm{H}^{+}\right], 341.17\left[\mathrm{M}^{+}+\mathrm{Na}^{+}\right]$. Elemental analysis calcd. for $\mathrm{C}_{16} \mathrm{H}_{18} \mathrm{~N}_{2} \mathrm{O}$, $\%$ : $\mathrm{C}, 60.37 ; \mathrm{H}$, 5.7; N, 8.8. Found, \%: C, 60.31; H, 5.76; N, 8.89.

\subsection{NMR experiments}

The NMR experiments were performed on a BRUKER FT NMR spectrometer AVANCE 300 (Bruker, Karlsruhe, Germany) (300 MHz for ${ }^{1} \mathrm{H}$ and $75 \mathrm{MHz}$ for ${ }^{13} \mathrm{C}$ ) with a BVT 3200 variable temperature unit in $5 \mathrm{~mm}$ sample tubes using Bruker Standard software (TopSpin 3.1). Chemical shifts were given in $\operatorname{ppm}(\delta)$ and were referenced to internal tetramethylsilane (TMS). Multiplicities are declared as follow: s (singlet), d (doublet), $\mathrm{t}$ (triplet), q (quadruplet), $\mathrm{m}$ (multiplet). Coupling constants $J$ are given in Hz. The experimental parameters for ${ }^{1} \mathrm{H}$ are as follows: digital resolution $=0.23 \mathrm{~Hz}, \mathrm{SWH}=7530 \mathrm{~Hz}, \mathrm{TD}=32 \mathrm{~K}, \mathrm{SI}=16 \mathrm{~K}, 90^{\circ}$ pulse-length $=10 \mathrm{~ms}$, $P L 1=3 \mathrm{~dB}, n s=1, d s=1, d l=1 \mathrm{~s}$ and for ${ }^{13} \mathrm{C}$ as follows: digital resolution=0.27 Hz, $S W H=17985$ $\mathrm{Hz}, T D=64 \mathrm{~K}, S I=32 \mathrm{~K}, 90^{\circ}$ pulse-length $=9 \mathrm{~ms}, P L I=1.5 \mathrm{~dB}, n s=500, d s=2, d l=3 \mathrm{~s}$. The NMRgrades DMSO- $\mathrm{d}_{6}\left(99.7 \%\right.$, containing $\left.0.3 \% \mathrm{H}_{2} \mathrm{O}\right), \mathrm{CDCl}_{3}$ were used for the solutions of synthesized compounds $\mathbf{4}$ and 5.

\subsection{Mass experiments}

High-resolution mass spectrometry (HRMS) was performed using electrospray ionization (ESI) in positive-ion or negative-ion detection mode.

\subsection{X-Ray analysis}

X-Ray analyses were performed on Bruker SMART APEX II Single Crystal X-ray Diffractometer equipped with graphite-monochromated Mo-K $\alpha$ radiation $(\lambda=0.71073 \AA)$ at 296(2) K, respectively. The crystal structure was solved by direct methods and refined on $F^{2}$ by full matrix least-squares using Bruker's SHELXTL-97 [53]. The details of the crystallographic data for synthesized compound are summarized in Table 1. Crystallographic data for the structural analysis have been deposited to the Cambridge Crystallographic Data Center under number CCDC 2014151.

\subsection{Hirshfeld surface analysis}

Hirshfeld surface and contact enrichment ratios were obtained with MoProViewer [54]. As $\mathrm{X} . . . \mathrm{Y}$ and $\mathrm{Y}$...X contacts yield similar contact surfaces and $E_{\text {elec }}$ values in the context of this study, the reciprocal contacts were merged together.

For the electrostatic energy calculation, the charge density parameters were transferred from the ELMAM2 database of multipolar atoms [55]. The $\mathrm{X}-\mathrm{H}$ bond lengths were elongated according to standard neutron diffraction distances [56]. The electrostatic energy was computed 
with the VMoPro module of MoPro software [57] between pairs of atoms in close contact up to a cutoff of sum of van der Waals radii plus $0.5 \AA$. The average $E_{\text {elec }}$ value was obtained by dividing the summation by the number of contacts. The energy of non-existent O...O contacts was computed at the cutoff distance.

\subsection{Biological assay}

The antibacterial activity of synthesized dihydropyrimidine derivatives $\mathbf{4}$ and $\mathbf{5}$ was studied against gram-negative $A$. baumanii, E. coli, P. aeruginosa and $K$. pneumoniae and gram-positive $S$. aureus bacteria by determining minimal inhibitory concentrations (MIC), which is the lowest concentration of compound that prevents the growth of bacterial cells after incubation. MIC was determined by the twofold micro-dilution method as described in [58]. The compounds were prepared according to CLSI guidelines and diluted in U-bottom 96 well microtiter plates which contained Muller Hinton Broth (MHB). The freshly prepared bacterial strains at about $10^{5} \mathrm{CFU}$ (colony forming unit) in MHB medium were added to each well of the microplate and incubated at $37^{\circ} \mathrm{C}$ for 24 hours. The concentration of the tested compounds ranged from 1000 to $7,8 \mu \mathrm{g} / \mathrm{mL}$. The growth of the bacterial cells was determined by resazurin method. The solution of resazurin sodium salt $(0.01 \%)$ was freshly prepared in sterile distilled water. After incubation, $30 \mu \mathrm{L}$ of this solution was added in each microplate well and incubated again at the same condition for about 4 h. MIC was represented as the lowest concentration of the compounds which inhibited the color change from blue to pink since pink color indicated the growth of bacteria [58]. MIC of the studied compound was compared with MICs of pristine antibiotics (cefotaxime and ceftriaxone).

Furthermore, the efficiency of the synthesized dihydropyrimidine against the abovementioned bacteria was also tested by disc-diffusion method as described by Mayrhofer [59]. In details, the surface of the nutrient medium (meat-peptone agar, Potato Dextrose Agar) was stratified with $1 \mathrm{~mL}$ of the diurnal suspension of the test culture $\left(10^{5} \mathrm{CFU} / \mathrm{mL}\right)$, which was used during $15 \mathrm{~min}$ after preparation. Previously prepared discs with certain concentrations were stratified on the surface of the nutrient medium by the sterile tweezers. Dishes were incubated at $37^{\circ} \mathrm{C}$ during $24 \mathrm{~h}$. DMSO was used as a solvent. Record of the results was carried out, compared with control dishes without compound and with the known drugs cefotaxime and ceftriaxone. The biological assays were carried out in triplicate. Standard deviations data were also calculated.

\section{Results and discussion}

\subsection{Chemical synthesis.}

First of all, the synthesis was started by performing Biginelli reaction on the basis of 2,4,6trimethoxybenzaldehyde, urea and acetylacetone in the presence of acetic acid [16] leading to the obtaining of new dihydropyrimidine 4 with $58 \%$ yield. The positive side of this protocol was simple work-up procedure - during cooling of the reaction mixture, the formed precipitate was washed just with distilled water. Among disadvantages, the high reaction time $(10 \mathrm{~h})$ and not so high yield of the desired product can be mentioned. This promoted us to search for a new procedure for this reaction. Performing Biginelli reaction in the presence of $\mathrm{Yb}(\mathrm{PFO})_{3}[60], \mathrm{I}_{2} / \mathrm{MWI}[61]$, 
[Hmim] $\mathrm{HSO}_{4}-\mathrm{NaNO}_{3}$ [62], TMSCl/CAN [63], $\mathrm{GaI}_{3}$ [64], $\mathrm{CAN}$ [65], $\mathrm{Sm}\left(\mathrm{ClO}_{4}\right)_{3}$ [66], $\mathrm{La}(\mathrm{OTf})_{3}$ [67], $\mathrm{RuCl}_{3}$ [68], $\mathrm{HBF}_{4}-\mathrm{SiO}_{2}$ [69], $\mathrm{H}_{3} \mathrm{PMo}_{12} \mathrm{O}_{40}$ [70], $\mathrm{Sc}(\mathrm{OTf})_{3}$ [71], $\mathrm{MgCl}_{2} \times 6 \mathrm{H}_{2} \mathrm{O}$ [72], $\mathrm{In}(\mathrm{OTf})_{3}$ [73] and $\mathrm{NH}_{4} \mathrm{Cl}$ [16] did not lead to the desired effect. Only improving the [74] procedure by performing the reaction in the presence of $\mathrm{Cu}(\mathrm{OTf})_{2}$ in microwave conditions allowed us to obtain targeted dihydropyrimidine with $80 \%$ yield. Another positive side of this procedure is that the reaction time was decreased four times from 10 to 2.5 hours (Scheme 1). The structure of synthesized novel dihydropyrimidine was determined by ${ }^{1} \mathrm{H},{ }^{13} \mathrm{C}$, dept $135 \mathrm{NMR}$, mass spectroscopy and elemental analysis. As it can be seen from ${ }^{1} \mathrm{H}$ NMR spectrum, the signals from methyl and methoxy groups are observed at 1.91, 2.11, 3.72 and $3.76 \mathrm{ppm}$ correspondingly, whereas the position of dihydropyrimidine core $\mathrm{CH}$ group is at $5.79 \mathrm{ppm}$. Their positions on ${ }^{13} \mathrm{C}$ NMR spectra are at 18.8, 28.9, 45.78, 55.19 and $55.74 \mathrm{ppm}$. The signals from amine groups of dihydropyrimidine core are observed at 7.03 and $8.95 \mathrm{ppm}$ respectively (Supplementary material).

The next step of synthesis was to perform regioselective oxidation of the synthesized dihydropyrimidine 4 in the presence of CAN. A small modification of the procedure [50] allowed the synthesis of the new pyrimidine 5 (Scheme 2). The structure of synthesized novel pyrimidine 5 was determined by ${ }^{1} \mathrm{H},{ }^{13} \mathrm{C}$, dept $135 \mathrm{NMR}$, mass spectroscopy and elemental analysis (Supplementary material). As it can be seen from ${ }^{1} \mathrm{H}$ NMR spectrum, the signals from the amine group and $\mathrm{CH}$ group of pyrimidine core have disappeared, which is a strong evidence of product 5 formation. The signals from methyl and methoxy groups are shifted to 1.95, 2.54, 3.75 and 3.87 ppm correspondingly. Their positions on ${ }^{13} \mathrm{C}$ NMR spectra are at 23.28, 30.05, 55.41 and $55.7 \mathrm{ppm}$ respectively.

\subsection{Structure description.}

It was also possible to obtain single crystals of the compound $\mathbf{4}$ by crystallization in methanol-ethyl acetate solution (9:1). The title compound crystallized in the triclinic system with space group $\mathrm{P}-1$ and $\mathrm{Z}=2$. The molecule of the title compound is built up from a 3,4-dihydropyrimidin-2 $(1 H)$-one ring linked to an acetyl group $\left(\mathrm{CH}_{3} \mathrm{CO}\right)$, a methyl group and a 2,4,6trimethoxyphenyl ring (Fig. 2). Crystallographic data and detailed refinement results of the compound $\mathbf{4}$ are presented in Table 1. The bond lengths and angles are given in Table S1, while hydrogen bonds present in the structure are shown in Table S2 (Supplementary material). 


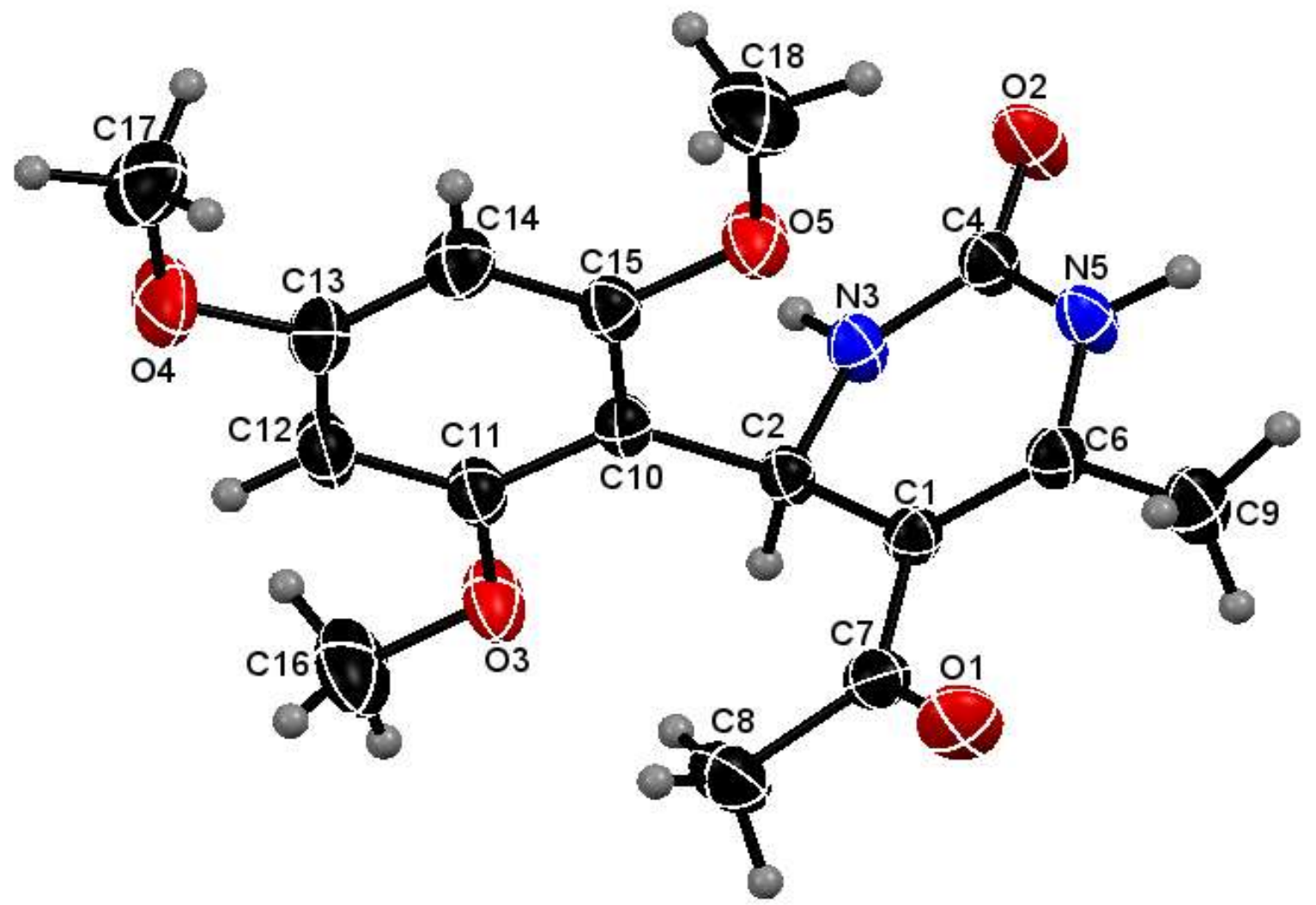

Figure 2. A view of the asymmetric unit of 5-acetyl-6-methyl-4-(2,4,6-trimethoxyphenyl)-3,4dihydropyrimidin-2 $(1 \mathrm{H})$-one, showing the atom labeling. Displacement ellipsoids are drawn at the $50 \%$ probability level.

The dihydropyrimidine ring (atoms N5-C4-N3-C2-C1-C6) adopts a boat conformation, as indicated by the puckering parameters: $Q_{2}=0.143$ (4) $\AA, \theta=72.53(2)^{\circ}$ and $\varphi=143.58(2)^{\circ}$. The mean plane through the ring is nearly perpendicular to the 2,4,6-trimethoxyphenyl ring, with which it makes a dihedral angle of $88.72^{\circ}$ (Fig. 3, Table S1).

The crystal packing of dihydropyrimidine $\mathbf{4}$ is formed via inter and intramolecular hydrogen bonding. There are five potential hydrogen bond donors, namely N3, N5, C2, C8 and C9 and five potential acceptors, namely the carbonyl oxygen atoms $\mathrm{O} 2^{\mathrm{ii}}[(\mathrm{ii})-\mathrm{x}+1,-\mathrm{y},-\mathrm{z}]$ and $\mathrm{O} 2^{\mathrm{iii}}[(\mathrm{iii}) \mathrm{x}-1, \mathrm{y}, \mathrm{z}]$, the acetyl oxygen $\mathrm{O} 1^{\mathrm{i}}(\mathrm{x}+1, \mathrm{y}, \mathrm{z})$ the methoxy oxygen $\mathrm{O} 3$.

Furthermore, the crystal packing of dihydropyrimidine $\mathbf{4}$ is formed by polar sheets with its functional groups involved in hydrogen bonds and by hydrophobic spacers which are formed by the phenyl moiety with its methoxy groups (Fig. 4). Dimeric motifs utilizing N3-H3 $\cdots \mathrm{O} 1^{\mathrm{i}}$ and $\mathrm{C} 9-\mathrm{H} 9 \mathrm{~B} \cdots \mathrm{O} 2^{\mathrm{iii}}$ hydrogen bonds can be described $\mathrm{R}_{2}^{2}(10)$ graph-set motif connecting two adjacent molecules involving the carbonyl group and $\mathrm{R}_{2}^{2}(8)$ which involved the ketone group in polar sheets along $a$-axis (Fig. 5, Table S2) [75]. 
Table 1. Crystallographic data and structure refinement for 5-acetyl-6-methyl-4-(2,4,6trimethoxyphenyl)-3,4-dihydropyrimidin-2(1H)-one (4).

\begin{tabular}{|l|l|}
\hline Chemical formula & $\mathrm{C}_{16} \mathrm{H}_{20} \mathrm{~N}_{2} \mathrm{O}_{5}$ \\
\hline$M_{\mathrm{r}}$ & 320.34 \\
\hline Crystal system, space group & Triclinic, $\mathrm{P}-1$ \\
\hline Temperature $(\mathrm{K})$ & 296 \\
\hline$a, b, c \quad(\AA)$ & $7.5197(4), 8.4695(4), 13.3399(8)$ \\
\hline$\alpha, \beta, \gamma\left(^{\circ}\right)$ & $96.231(2), 100.613(2), 99.357(2)$ \\
\hline$V\left(\AA^{3}\right)$ & $815.50(8)$ \\
\hline$Z$ & 2 \\
\hline Radiation type & Mo $K \alpha$ \\
\hline Absorption $\mu\left(\mathrm{mm}^{-1}\right)$ & 0.10 \\
\hline Crystal size $\left(\mathrm{mm}^{-1}\right)$ & $0.82 \times 0.62 \times 0.60$ \\
\hline$T_{\min ,} T_{\max }$ & $0.641,0.746$ \\
\hline$R_{\text {int }}$ & 0.024 \\
\hline $\sin \theta_{\max } / \lambda \quad\left(\AA^{-1}\right)$ & 0.682 \\
\hline$R\left[F^{2}>2 \sigma\left(F^{2}\right)\right], w R\left(F^{2}\right), S$ & $0.056,0.169,1.05$ \\
\hline$\Delta \rho_{\max }, \Delta \rho_{\min }\left(\mathrm{e} \AA^{-3}\right)$ & $0.31,-0.27$ \\
\hline
\end{tabular}

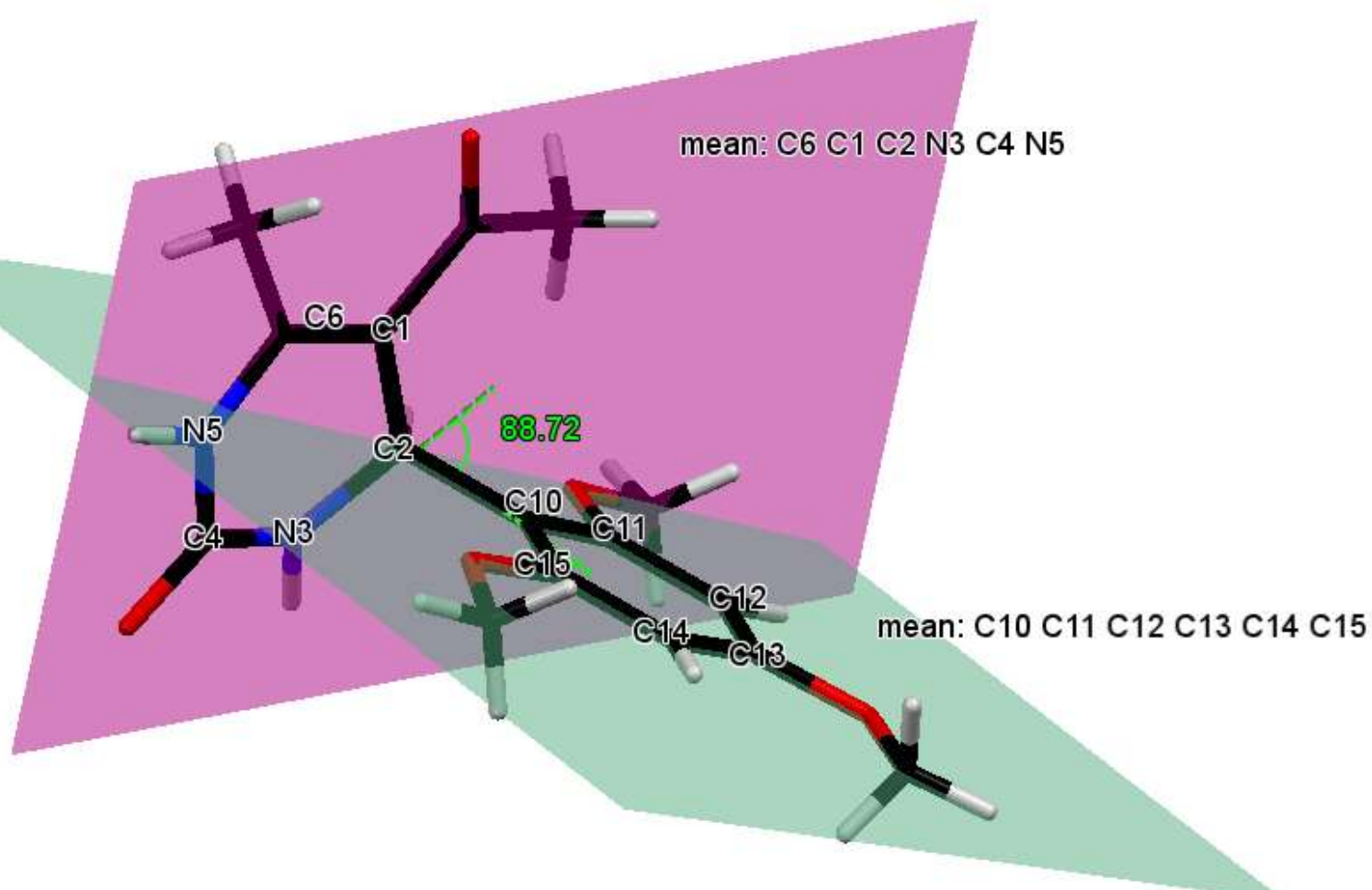

Figure 3. Dihedral angle between the planes of 3,4-dihydropyrimidin-2(1H)-one ring and the 2,4,6-trimethoxyphenyl ring in the compound 4 . 


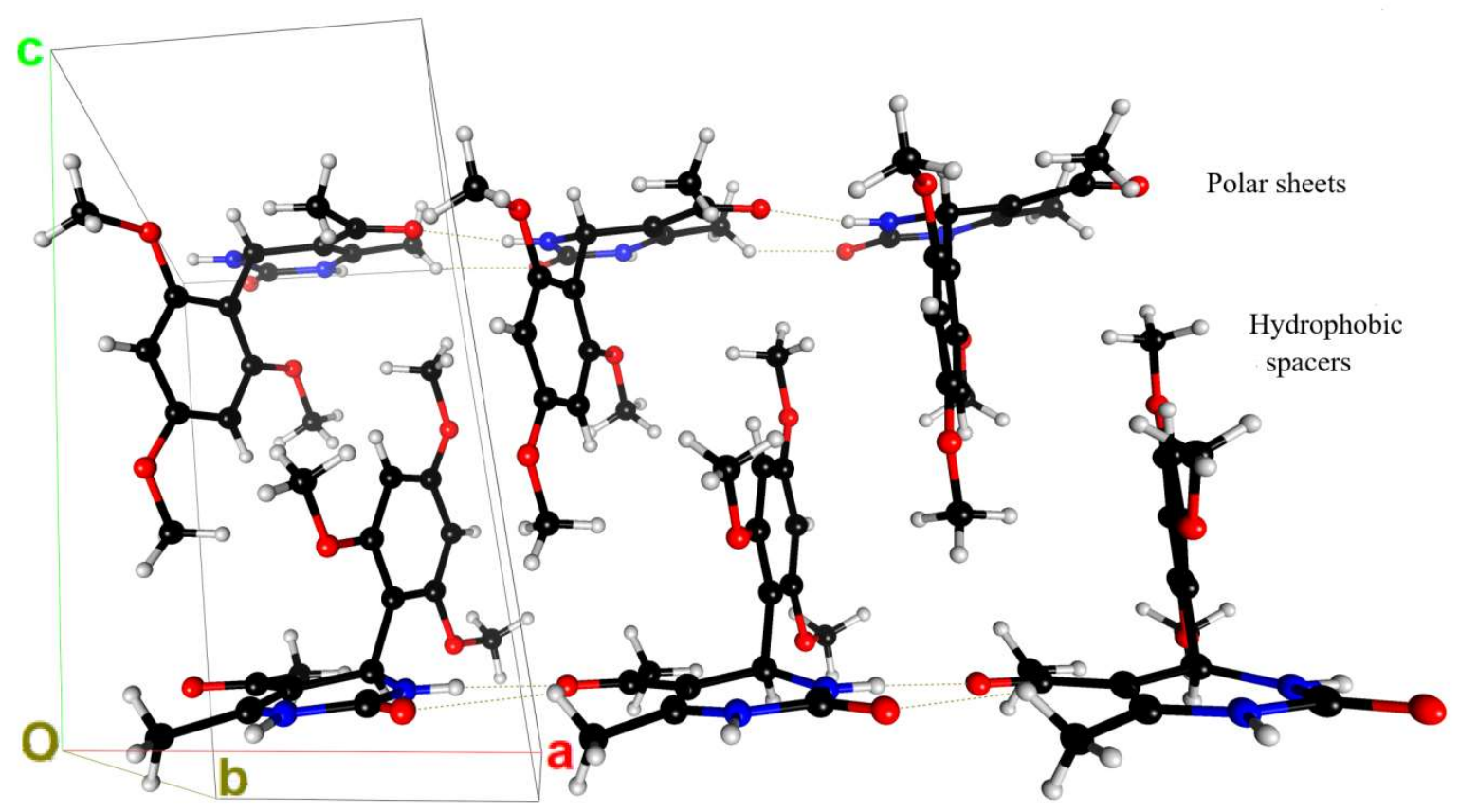

Figure 4. Crystallographic autostereogram view of the dihydropyrimidine 4 crystal packing along the $b$-axis. Dotted lines indicate N-H...O and C-H...O hydrogen bonds.

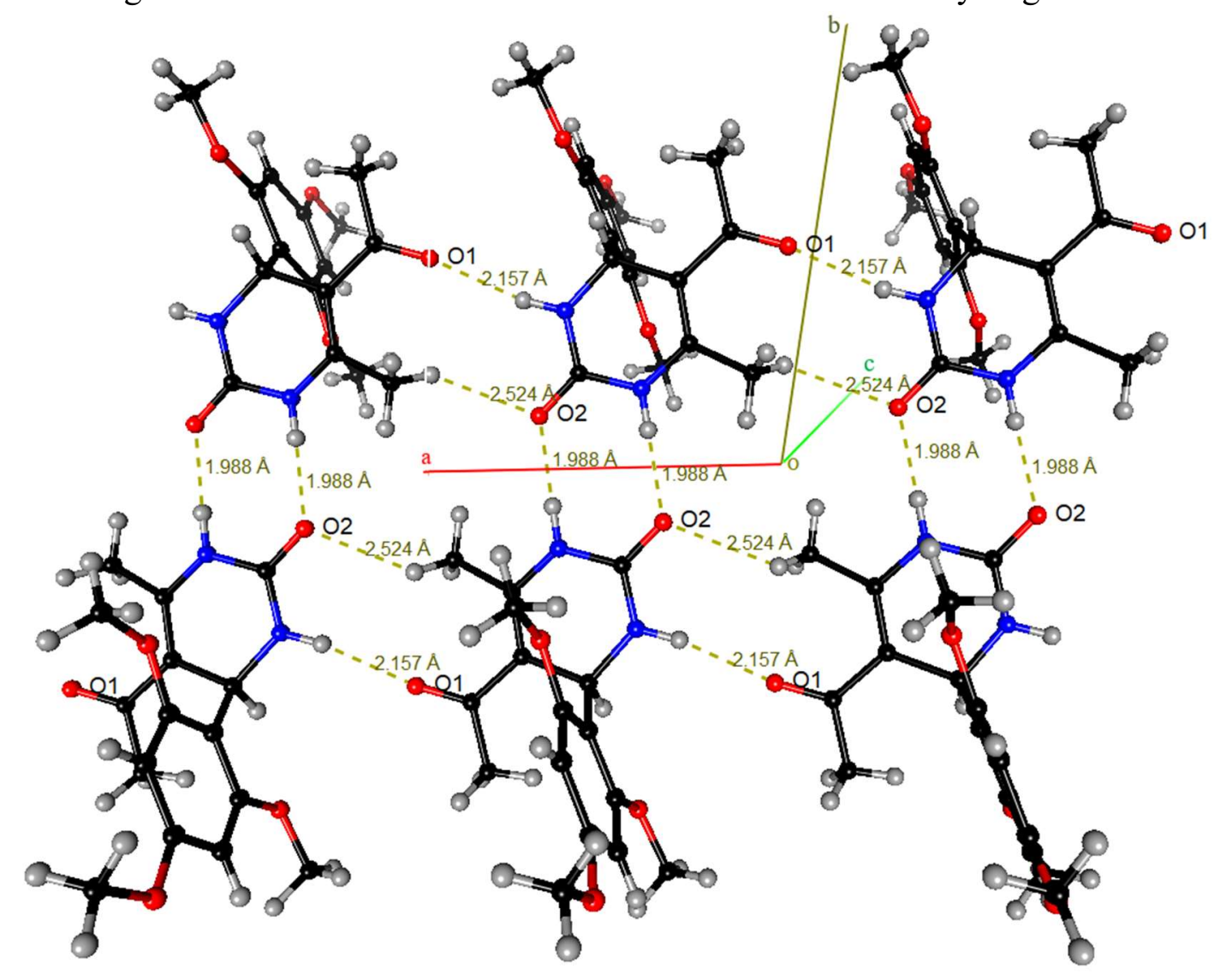

Figure 5. Autostreogram view of packing crystal parallel to $(a b)$ plane, showing molecules linked through $\mathrm{C}-\mathrm{H} \cdots \mathrm{O}$ and $\mathrm{N}-\mathrm{H} \cdots \mathrm{O}$ hydrogen bonds (dashed lines). 
Within the dihydropyrimidin-2(1H)-one rings, an examination of the bond length data

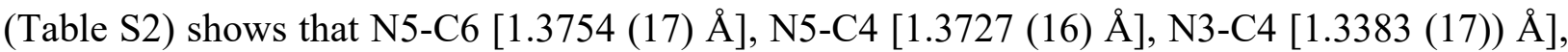
and N3-C2 [1.4725 (16) $\AA]$ can be attributed as having clear single bond character. The C1-C7

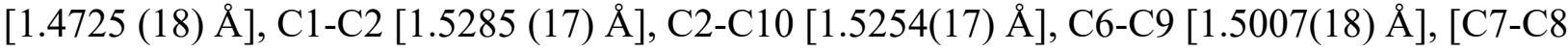
1.505(2) $\AA$ ] distances are in agreement with the presence of the $\mathrm{C}-\mathrm{C}$ single bonds. Also, these phenyl moieties exhibit a regular spatial configuration with normal $\mathrm{C}-\mathrm{C}$ distances and $\mathrm{C}-\mathrm{C}-\mathrm{C}$ angles. The average value of the $\mathrm{C}-\mathrm{C}$ bond lengths of the phenyl rings is 1.397 (3) and 1.388 (3) $\AA$ A which are between a single and double bond and agree with those in the literature [76, 77]. The conformation of the dihydropyrimidin-2(1H)-one ring defined by the torsion angles $\mathrm{C} 4-\mathrm{N} 5-\mathrm{C} 6-$ C9, C6-N5-C4-O2, C6-C1-C7-O1 and C6-C1-C7-C8 of experimentally $170.03(14)^{\circ},-176.62$ $(14)^{\circ}, 11.1(2)^{\circ}$ and $-170.10(4)^{\circ}$. The aromatic rings are planar with a r.m.s. (root-mean-square) deviation of $0.016 \AA$ for the $\mathrm{C} 10 / \mathrm{C} 11 / \mathrm{C} 12 / \mathrm{C} 13 / \mathrm{C} 14 / \mathrm{C} 15$ ring and $-0.097 \AA$ for the $\mathrm{C} 1 / \mathrm{C} 2 / \mathrm{N} 3 / \mathrm{C} 4 / \mathrm{N} 5 / \mathrm{C} 6$ ring.

No stacking interactions are observed between neighboring aromatic rings in the molecular packing but the cohesion structure is ensured by weak C-H... $\pi$ hydrogen bonds. Indeed, the distances between the $\mathrm{H} 17 \mathrm{~B}$ and $\mathrm{H} 18 \mathrm{C}$ hydrogen atoms and the centroids $\mathrm{Cg} 1$ and $\mathrm{Cg} 2$ of two neighboring $\mathrm{C} 10-\mathrm{C} 11-\mathrm{C} 12-\mathrm{C} 13-\mathrm{C} 14-\mathrm{C} 15$ phenyl rings, at $\mathrm{x}, \mathrm{y}, \mathrm{z}$ and $1-\mathrm{x}, 1-\mathrm{y}, 1-\mathrm{z}$ symmetry codes, vary between $3.786 \AA$ and $3.852 \AA$ (Fig. 6).

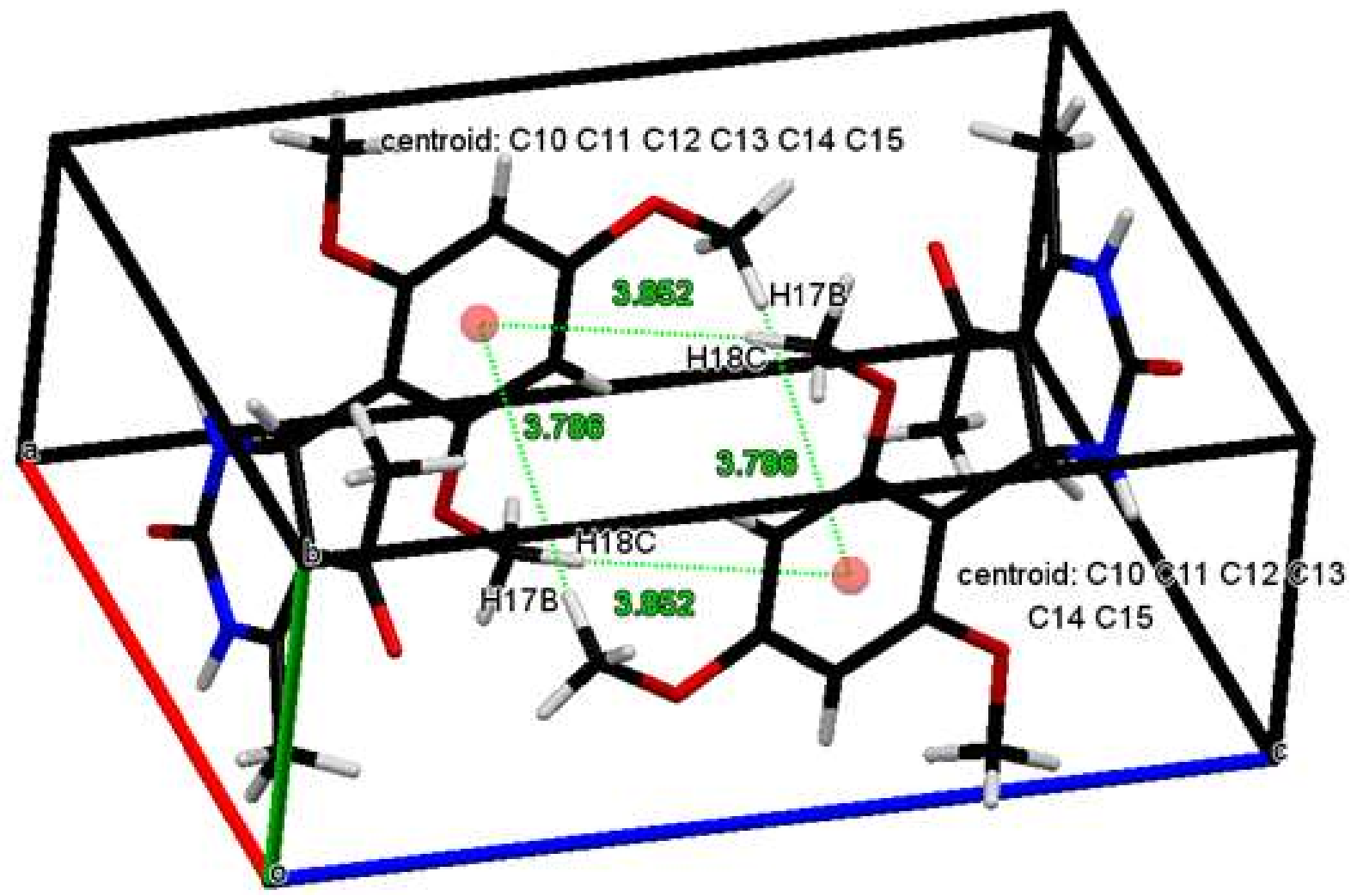

Figure 6. View of C-H $\ldots \pi$ intermolecular interactions in the crystal unit cell of compound 4. 


\subsection{Hirshfeld surface analysis.}

The Hirshfeld surface is representative of the region in crystalline space where molecules come into contact allowing the analysis of the chemical nature of intermolecular interactions. Table 2 shows the proportions $C_{\mathrm{xy}}$ of the different contact types. The enrichment ratio $E_{\mathrm{xy}}$ is obtained by comparing the actual contacts $C_{\mathrm{xy}}$ with those computed as if all contacts had the same probability to form. An enrichment ratio larger than unity indicates that the contact type is overrepresented in the crystal $[78,79]$.

The fingerprint plot (Fig. 7, Supplementary material) shows two spikes at short distance corresponding the strong hydrogen bonds $\mathrm{N}-\mathrm{H} \ldots \mathrm{O}=\mathrm{C}$. The other spike at shortest distance concern the H...H contacts with $d(\mathrm{H}, \mathrm{H})$ as low as $2.2 \AA$. The C...H weak hydrogen bonds appear in the fingerprint at longer distances $d>2.8 \AA$. The N...H contacts are not hydrogen bonds as the $\mathrm{sp}^{2}$ nitrogen atoms have three covalent bonds and no lone pair.

The hydrophobic Hc atoms occupy more than half of the Hirshfeld surface and Hc...Hc contacts have the highest proportion at on third (Table 2 ) and are equi-represented $(E=1)$. Globally hydrophobic atoms $\mathrm{C}$ and $\mathrm{Hc}$ represent nearly $80 \%$ of the surface and their contacts at $63 \%$ are slightly over-represented $(E=1.03)$.

The strongest possible hydrogen bond for this molecule is of $\mathrm{C}=\mathrm{O} \ldots . \mathrm{H}-\mathrm{N}$ type. The two $\mathrm{N}-\mathrm{H}$ donors and two $\mathrm{C}=\mathrm{O}$ acceptors do form such a hydrogen bond and this contact type is the most enriched $E(\mathrm{Hn}, \mathrm{O}=\mathrm{c})=4.9$. The crystal packing of the title compound is consistent with the often quoted Etter rule of the best donor-best acceptor pairing of hydrogen bonds [80]. On the other hand, the ether oxygen atoms Occ which are weaker acceptors are more interacting with the Hc hydrogen atoms and this contact is moderately over-represented $(E=1.34)$.

The average electrostatic energy $E_{\text {elec }}$ between the atom pairs in contact was computed for the different types. The scatterplot of $E_{\text {elec }}$ and of contacts enrichment $E$ (Fig. 8, Supplementary material) shows that the Oc...Hn interaction is an outlier in the graph with much higher $E$ and $E_{\text {elec }}$ values than the other contact types and is the major driving force of the crystal stabilization. The 
weak H-bond Hc...Occ appears next in the region of high $E$ values and most favorable $E_{\text {elec }}$ values. The oxygen...carbon stacking contacts appears attractive according to the $E_{\text {elec }}$ values although there are slightly under-represented.

Table 2. Statistical analysis of intermolecular contacts on the Hirshfeld surface. The second row shows the chemical content on the Hirshfeld surface. The middle part shows the proportions $C_{\mathrm{xy}}$ of the different contact types and the lower part shows the $E_{\mathrm{xy}}$ enrichment ratios of contact types. Reciprocal contact types X...Y and Y...X are merged. The main contacts and the most enriched ones are highlighted in bold. The hydrogen atoms bound to carbon Hc and to nitrogen Hn were distinguished as they have different charge character. The strong $\mathrm{H}$-bond acceptor $\mathrm{O}=\mathrm{C}$ oxygen carbonyl was also distinguished from the ether oxygen.

\begin{tabular}{|l|ccccc|}
\hline atom & $\mathrm{C}$ & $\mathrm{Hc}$ & $\mathrm{Occ}$ & $\mathrm{O}=\mathrm{c}$ & $\mathrm{Hn}$ \\
$\%$ & $\mathbf{2 1 . 2}$ & $\mathbf{5 8 . 3}$ & 4.2 & 8.9 & 6.2 \\
\hline $\mathrm{C}$ & 5.1 & & & & \\
$\mathrm{Hc}$ & $\mathbf{2 6 . 4}$ & $\mathbf{3 3 . 5}$ & & & \\
$\mathrm{Occ}$ & 1.3 & $\mathbf{6 . 2}$ & 0 & & \\
$\mathrm{O}=\mathrm{c}$ & 2.1 & $\mathbf{1 0 . 4}$ & 0.4 & 0.1 & \\
$\mathrm{Hn}$ & 0.6 & 5.2 & 0.2 & $\mathbf{5 . 7}$ & 0.5 \\
\hline $\mathrm{C}$ & $\mathbf{1 . 1 7}$ & & & & \\
$\mathrm{Hc}$ & $\mathbf{1 . 0 9}$ & 1.00 & & & \\
$\mathrm{Occ}$ & 0.79 & $\mathbf{1 . 3 4}$ & 0 & & \\
$\mathrm{O}=\mathrm{c}$ & 0.53 & 0.96 & 0 & 0.50 & \\
$\mathrm{Hn}$ & 0.24 & 0.72 & 0.33 & $\mathbf{4 . 9}$ & 1.14 \\
\hline
\end{tabular}

\subsection{Biological assays}

The antibacterial activity of the synthesized dihydropyrimidine was investigated against gram-negative $A$. baumanii, E. coli, $P$. aeruginosa and $K$. pneumoniae and gram-positive $S$. aureus bacteria. Biological activity investigations were started with the determination of minimum inhibitory concentration (MIC) for the synthesized novel compound $\mathbf{4}$ and $\mathbf{5}$ and pristine antibiotics (cefotaxime and ceftriaxone) by the twofold micro-dilution method. As shown in Table 3, the synthesized dihydropyrimidine $\mathbf{4}$ activity was similar to the ceftriaxone one in case of $S$. aureus $(31.2 \mu \mathrm{g} / \mu \mathrm{L})$, whereas in case of A. baumanii, E. coli, P. aeruginosa and K. pneumoniae bacteria MICs were higher compared to both pristine antibiotics. MIC of compound (5) was similar to ceftriaxone result $(62.5 \mu \mathrm{g} / \mu \mathrm{L})$ in case of $K$. pneumoniae, whereas in case of all other bacteria it was two times lower. Comparative analysis of compound 5 MICs with cefotaxime demonstrated that just, in case of was K. pneumoniae, it was two times higher than cefotaxime $(62.5 \mu \mathrm{g} / \mu \mathrm{L})$, 
whereas for all other bacteria, the results were similar to cefotaxime.

Table 3. Minimum inhibitory concentration (MIC, $\mu \mathrm{g} / \mu \mathrm{L}$ ) of the studied compounds.

\begin{tabular}{|c|cccc|}
\hline \multirow{2}{*}{ Bacteria } & \multicolumn{4}{|c|}{ Minimum inhibitory concentration (MIC, $\mu \mathrm{g} / \mu \mathrm{L})$} \\
\cline { 2 - 5 } & Compound (4) & Compound (5) & Cefotaxime & Ceftriaxone \\
\hline E. coli & 62.5 & 15.6 & 15.6 & 31.2 \\
P. aeruginosa & 500 & 31.2 & 31.2 & 62.5 \\
A. baumanii & 500 & 31.2 & 31.2 & 62.5 \\
K. pneumoniae & 500 & 62.5 & 31.2 & 62.5 \\
S. aureus & 31.2 & 15.6 & 15.6 & 31.2 \\
\hline
\end{tabular}

Table 4. Antibacterial activity of novel dihydropyrimidine 4.

\begin{tabular}{|cccccccc|}
\hline E.coli & \multicolumn{4}{c}{ compound (4) } & cefotaxime & ceftriaxone \\
\hline $\begin{array}{c}\text { Concentration } \\
(\mu \mathrm{g} / \mu \mathrm{l})\end{array}$ & 62.5 & 125 & 250 & 500 & 1000 & 1000 & 1000 \\
\hline Inhibition zone $(\mathrm{mm})$ & 3 & 7 & 15 & 22 & 30 & 40 & 32 \\
\hline
\end{tabular}

\begin{tabular}{|ccccccccc|}
\hline P.aeruginosa & \multicolumn{4}{c}{ compound (4) } & cefotaxime & ceftriaxone \\
\hline $\begin{array}{c}\text { Concentration } \\
(\mu \mathrm{g} / \mu \mathrm{l})\end{array}$ & 500 & 1000 & 1500 & 2000 & 2500 & 2500 & 2500 \\
\hline Inhibition zone $(\mathrm{mm})$ & 2 & 6 & 14 & 20 & 28 & 45 & 45 \\
\hline
\end{tabular}

\begin{tabular}{|cccccccc|}
\hline A.baumanii & \multicolumn{4}{c}{ compound (4) } & cefotaxime & ceftriaxone \\
\hline $\begin{array}{c}\text { Concentration } \\
(\mu \mathrm{g} / \mu \mathrm{l})\end{array}$ & 500 & 1000 & 1500 & 2000 & 2500 & 2500 & 2500 \\
\hline Inhibition zone $(\mathrm{mm})$ & 2 & 5 & 9 & 15 & 24 & 45 & 45 \\
\hline
\end{tabular}

\begin{tabular}{|ccccccccc|}
\hline K.pneumoniae & \multicolumn{4}{c}{ compound (4) } & cefotaxime & ceftriaxone \\
\hline $\begin{array}{c}\text { Concentration } \\
(\mu \mathrm{g} / \mu \mathrm{l})\end{array}$ & 500 & 1000 & 1500 & 2000 & 2500 & 2500 & 2500 \\
\hline Inhibition zone $(\mathrm{mm})$ & 3 & 8 & 13 & 20 & 31 & 45 & 45 \\
\hline
\end{tabular}

\begin{tabular}{|cccccccc|}
\hline S.aureus & \multicolumn{4}{c}{ compound (4) } & cefotaxime & ceftriaxone \\
\hline $\begin{array}{c}\text { Concentration } \\
(\mu \mathrm{g} / \mu \mathrm{l})\end{array}$ & 31.2 & 62.5 & 125 & 250 & 500 & 500 & 500 \\
\hline Inhibition zone $(\mathrm{mm})$ & 3 & 5 & 9 & 15 & 28 & 34 & 26 \\
\hline
\end{tabular}


Taking into account the MIC of the compounds, antibacterial activity was also investigated by disc-diffusion method. Results were compared with the antibacterial activity of pristine antibiotics. As it can be seen from Table 4, the antibacterial activity of the novel dihydropyrimidine 4 against $S$. aureus was higher than that of pristine antibiotic ceftriaxone, equal to 28 and $26 \mathrm{~mm}$ inhibition disk radius correspondingly. The same tendency was not observed in case of all gram-negative bacteria, where the antibacterial activity of compound $\mathbf{4}$ was lower than that of both pristine antibiotics cefotaxime and ceftriaxone (Table 4).

In comparison to compound $\mathbf{4}$, the antibacterial activity of compound $\mathbf{5}$ was higher against all mentioned bacteria. In case of E.coli, the antibacterial activity of compound $\mathbf{5}$ was higher than that of ceftriaxone but lower than cefotaxime, equal to $20,17,22 \mathrm{~mm}$ respectively. Looking at the inhibition zone of compound $\mathbf{5}$ in the case of K.pneumoniae, it was equal to ceftriaxone one (29 $\mathrm{mm}$ ) but lower than cefotaxime $(36 \mathrm{~mm})$. A positive trend was observed in case of $P$. aeruginosa, A. baumanii and $S$. aureus, where the antibacterial activity of compound 5 was higher than that of the two pristine antibiotics cefotaxime and ceftriaxone (Table 5).

Table 5. Antibacterial activity of novel pyrimidine $\mathbf{5}$.

\begin{tabular}{|cccccccc|}
\hline E.coli & \multicolumn{4}{c}{ compound (5) } & cefotaxime & ceftriaxone \\
\hline $\begin{array}{c}\text { Concentration } \\
(\mu \mathrm{g} / \mu \mathrm{l})\end{array}$ & 15.6 & 31.2 & 62.5 & 125 & 250 & 250 & 250 \\
\hline Inhibition zone $(\mathrm{mm})$ & 3 & 5 & 9 & 14 & 20 & 22 & 17 \\
\hline
\end{tabular}

\begin{tabular}{|cccccccc|}
\hline P.aeruginosa & \multicolumn{4}{c}{ compound (5) } & cefotaxime & ceftriaxone \\
\hline $\begin{array}{c}\text { Concentration } \\
(\mu \mathrm{g} / \mu \mathrm{l})\end{array}$ & 31.2 & 62.5 & 125 & 250 & 500 & 500 & 500 \\
\hline Inhibition zone $(\mathrm{mm})$ & 2 & 5 & 14 & 23 & 30 & 28 & 21 \\
\hline
\end{tabular}

\begin{tabular}{|cccccccc|}
\hline A.baumanii & \multicolumn{4}{c}{ compound (5) } & cefotaxime & ceftriaxone \\
\hline $\begin{array}{c}\text { Concentration } \\
(\mu \mathrm{g} / \mu \mathrm{l})\end{array}$ & 31.2 & 62.5 & 125 & 250 & 500 & 500 & 500 \\
\hline Inhibition zone $(\mathrm{mm})$ & 5 & 13 & 20 & 30 & 38 & 35 & 29 \\
\hline
\end{tabular}

\begin{tabular}{|ccccccccc|}
\hline K.pneumoniae & \multicolumn{4}{c}{ compound (5) } & cefotaxime & ceftriaxone \\
\hline $\begin{array}{c}\text { Concentration } \\
(\mu \mathrm{g} / \mu \mathrm{l})\end{array}$ & 62.5 & 125 & 250 & 500 & 1000 & 1000 & 1000 \\
\hline Inhibition zone $(\mathrm{mm})$ & 4 & 9 & 15 & 21 & 29 & 36 & 29 \\
\hline
\end{tabular}

\begin{tabular}{|cccccccc|}
\hline \multicolumn{1}{|c}{ S.aureus } & \multicolumn{4}{c}{ compound (5) } & cefotaxime & ceftriaxone \\
\hline Concentration $(\mu \mathrm{g} / \mu \mathrm{l})$ & 15.6 & 31.2 & 62.5 & 125 & 250 & 250 & 250 \\
\hline Inhibition zone $(\mathrm{mm})$ & 5 & 11 & 18 & 25 & 31 & 28 & 21 \\
\hline
\end{tabular}


Taking into account that DMSO, which was used as a solvent, is an example of a compound able to demonstrate biological activity, the record of the results was also carried out with control dishes without investigated compound. It was determined that DMSO does not influence on the above mentioned gram-positive and gram-negative bacteria.

\section{Conclusion.}

The new derivative of pyrimidine $\mathbf{5}$ was synthesized by the CAN mediated regioselective oxidation of novel dihydropyrimidine 4 which was obtained by Biginelli reaction in microwave conditions in presence of copper triflate. The structure of novel dihydropyrimidine 4 was investigated by X-ray single crystal diffraction. Along with it, Hirshfeld surface analysis was carried out to gain insight into the crystal packing and molecular interactions. Considering that the proposed substances $\mathbf{4}$ and $\mathbf{5}$ can have an ability to act as an antibacterial drug, they were tested for their biological activity against gram-negative A. baumanii, E. coli, P. aeruginosa and K. pneumoniae and gram-positive $S$. aureus bacteria. A comparison with the activities of pristine antibiotics cefotaxime and ceftriaxone was made. According to the antibacterial activity results, compound $\mathbf{5}$ demonstrates pronounced antibacterial activity in comparison to compound $\mathbf{4}$ and pristine antibiotics. In the future, by applying innovative technologies, they could lead to the creation of new effective antibacterial drugs.

\section{Conflict of Interest}

The authors declare no conflict of interest.

\section{Funding}

This work was supported by the Erasmus + overseas/ICM KA107 programme.

\section{References}

1. Kappe, C. Oliver. "The generation of dihydropyrimidine libraries utilizing Biginelli multicomponent chemistry." QSAR \& combinatorial science $22.6 \quad$ (2003): 630-645. https://doi.org/10.1002/qsar.200320001

2. C.O. Kappe. "Recent advances in the Biginelli dihydropyrimidine synthesis. New tricks from an old dog", Accounts of Chemical Research 33.12 (2000): 879-888. https://doi.org/10.1021/ar000048h

3. N. Honnappa, A. Mukhopadhyay and J.N. Moorthy. "Biginelli reaction: an overview", Tetrahedron Letters 57.47 (2016): 5135-5149. https://doi.org/10.1016/j.tetlet.2016.09.047

4. S.S. Jagir "Past, present and future of the Biginelli reaction: a critical perspective." ARKIVOC: Online Journal of Organic Chemistry (2012): 66-133. http://dx.doi.org/10.3998/ark.5550190.0013.103

5. E. Woerly. "The Biginelli Reaction: Development and Application", Organic chemistry seminar at the University of Illinois, 2008: 1-8. http://www.chemistry.illinois.edu/research/organic/seminar_abstracts/seminar_abstracts_2008_2009 .html. 
6. C.O. Kappe. "100 Years of the Biginelli Dihydropyrimidine Synthesis”, Tetrahedron 1993, 49, 69376963. https://doi.org/10.1016/S0040-4020(01)87971-0

7. Rashid, Umer, et al. "Structure based medicinal chemistry-driven strategy to design substituted dihydropyrimidines as potential antileishmanial agents." European journal of medicinal chemistry 115 (2016): 230-244. https://doi.org/10.1016/j.ejmech.2016.03.022

8. Klein, Emmanuel, et al. "New chemical tools for investigating human mitotic kinesin Eg5." $\begin{array}{llllll}\text { Bioorganic } \quad \& \quad \text { medicinal } & \text { chemistry } & 15.19 & \text { (2007): }\end{array}$ https://doi.org/10.1016/j.bmc.2007.06.016

9. Kaan, Hung Yi Kristal, et al. "Structural basis for inhibition of Eg5 by dihydropyrimidines: stereoselectivity of antimitotic inhibitors enastron, dimethylenastron and fluorastrol." Journal of medicinal chemistry 53.15 (2010): 5676-5683. https://doi.org/10.1021/jm100421n

10. Wright, Christine M., et al. "Pyrimidinone-peptoid hybrid molecules with distinct effects on molecular chaperone function and cell proliferation." Bioorganic \& medicinal chemistry 16.6 (2008): 32913301. https://doi.org/10.1016/j.bmc.2007.12.014

11. Agbaje, Oluropo C., et al. "Synthesis and in vitro cytotoxicity evaluation of some fluorinated hexahydropyrimidine derivatives." Bioorganic \& medicinal chemistry letters 21.3 (2011): 989992.https://doi.org/10.1016/j.bmcl.2010.12.022

12. Kumar, BR Prashantha, et al. "Novel Biginelli dihydropyrimidines with potential anticancer activity: a parallel synthesis and CoMSIA study." European journal of medicinal chemistry 44.10 (2009): 4192-4198. https://doi.org/10.1016/j.ejmech.2009.05.014

13. Ibrahim, Diaa A., and Amira M. El-Metwally. "Design, synthesis, and biological evaluation of novel pyrimidine derivatives as CDK2 inhibitors." European journal of medicinal chemistry 45.3 (2010): 1158-1166. https://doi.org/10.1016/i.ejmech.2009.12.026

14. Li, Song, et al. "Dihydropyrimidine compounds and their uses in preparation of medicaments for treating and preventing antiviral diseases." U.S. Patent No. 8,168,642. 2012.

15. Watabe, Tadashi, Kenichiro Ogura, and Takahito Nishiyama. "Molecular toxicological mechanism of the lethal interactions of the new antiviral drug, sorivudine, with 5-fluorouracil prodrugs and genetic deficiency of dihydropyrimidine dehydrogenase." Yakugaku zasshi: Journal of the Pharmaceutical Society of Japan 122.8 (2002): 527. doi: 10.1248/yakushi.122.527.

16. A.M. Maharramov, et al. "Synthesis, investigation of the new derivatives of dihydropyrimidines and determination of their biological activity", Journal of Molecular Structure 1141 (2017): 39-43. https://doi.org/10.1016/j.molstruc.2017.03.084

17. Awadallah, Fadi M., et al. "Synthesis of some dihydropyrimidine-based compounds bearing pyrazoline moiety and evaluation of their antiproliferative activity." European journal of medicinal chemistry 70 (2013): 273-279. https://doi.org/10.1016/j.ejmech.2013.10.003

18. Oie, Shinji, et al. "Alteration of dihydropyrimidine dehydrogenase expression by IFN- $\alpha$ affects the antiproliferative effects of 5-fluorouracil in human hepatocellular carcinoma cells." Molecular Cancer Therapeutics 6.8 (2007): 2310-2318. DOI: 10.1158/1535-7163

19. (a) Wang, Anqi, et al. "New magnetic nanocomposites of $\mathrm{ZrO}_{2}-\mathrm{Al}_{2} \mathrm{O}_{3}-\mathrm{Fe}_{3} \mathrm{O}_{4}$ as green solid acid catalysts in organic reactions." Catalysis Science \& Technology 4.1 (2014): 71-80. 
DOI: 10.1039/C3CY00572K ; (b) Ghosh, Barun Kumar, Subhenjit Hazra, and Narendra Nath Ghosh. "Synthesis ofCu@CF@SBA15: A Versatile catalysts for (i) reduction of dyes, trifluralin, Synthesis of (ii) DHPMs by Biginelli reaction and (iii) 1, 2, 3-triazole derivatives by 'Click reaction'." Catalysis Communications 80 (2016): 44-48. https://doi.org/10.1016/j.catcom.2016.03.016

20. (a) October, Natasha, et al. "Reversed Chloroquines Based on the 3, 4-Dihydropyrimidin-2 (1H)-one Scaffold: Synthesis and Evaluation for Antimalarial, $\beta$-Haematin Inhibition, and Cytotoxic Activity." ChemMedChem: Chemistry Enabling Drug Discovery 3.11 (2008): 1649-1653. https://doi.org/10.1002/cmdc.200800172; (b) Fatima, Seerat, et al. "One pot efficient diversity oriented synthesis of polyfunctional styryl thiazolopyrimidines and their bio-evaluation as antimalarial and anti-HIV agents." European journal of medicinal chemistry 55 (2012): 195-204. https://doi.org/10.1016/j.ejmech.2012.07.018; (c) Kaur, Hardeep, et al. "Primaquine-pyrimidine hybrids: synthesis and dual-stage antiplasmodial activity." European journal of medicinal chemistry 101 (2015): 266-273. https://doi.org/10.1016/j.ejmech.2015.06.045

21. (a) Akhaja, Tarunkumar Nanjibhai, and Jignesh Priyakant Raval. "1, 3-Dihydro-2H-indol-2-ones derivatives: Design, synthesis, in vitro antibacterial, antifungal and antitubercular study." European journal of medicinal chemistry $46.11 \quad$ (2011): 5573-5579. https://doi.org/10.1016/j.ejmech.2011.09.023; (b) Yadlapalli, Rama Krishna, et al. "Synthesis and in vitro anticancer and antitubercular activity of diarylpyrazole ligated dihydropyrimidines possessing lipophilic carbamoyl group." Bioorganic \& medicinal chemistry letters 22.8 (2012): 2708-2711. https://doi.org/10.1016/j.bmcl.2012.02.101

22. Mokale, Santosh N., et al. "Synthesis and anti-inflammatory activity of some 3-(4, 6-disubtituted-2thioxo-1, 2, 3, 4-tetrahydropyrimidin-5-yl) propanoic acid derivatives." Bioorganic \& medicinal chemistry letters 20.15 (2010): 4424-4426. https://doi.org/10.1016/j.bmcl.2010.06.058

23. Bahekar, Sushilkumar S., and Devanand B. Shinde. "Synthesis and anti-inflammatory activity of some [4, 6-(4-substituted aryl)-2-thioxo-1, 2, 3, 4-tetrahydro-pyrimidin-5-yl]-acetic acid derivatives." Bioorganic \& medicinal chemistry letters $14.7 \quad$ (2004): 1733-1736. https://doi.org/10.1016/j.bmcl.2004.01.039

24. Marathwada, Babasaheb Ambedkar. "Synthesis and anti-inflammatory activity of some [2-amino-6(4-substituted aryl)-4-(4-substituted phenyl)-1, 6-dihydropyrimidine-5-yl]-acetic acid derivatives." Acta Pharm 53 (2003): 223-229.

25. Atwal, Karnail S., et al. "Dihydropyrimidine calcium channel blockers: 2-heterosubstituted 4aryl-1, 4-dihydro-6-methyl-5-pyrimidinecarboxylic acid esters as potent mimics of dihydropyridines." Journal of medicinal chemistry 33.5 (1990): 1510-1515. https://doi.org/10.1021/jm00167a035

26. Zorkun, Inci Selin, et al. "Synthesis of 4-aryl-3, 4-dihydropyrimidin-2 (1H)-thione derivatives as potential calcium channel blockers." Bioorganic \& medicinal chemistry 14.24 (2006): 85828589. https://doi.org/10.1016/j.bmc.2006.08.031

27. Chikhale, R. V., et al. "Synthesis and pharmacological investigation of 3-(substituted 1phenylethanone)-4-(substituted phenyl)-1, 2, 3, 4-tetrahydropyrimidine-5-carboxylates." 
European journal of medicinal chemistry $44.9 \quad$ (2009): 3645-3653. https://doi.org/10.1016/j.ejmech.2009.02.021

28. Lewis, Ryan W., et al. "Dihydropyrimidinone positive modulation of $\delta$-subunit-containing $\gamma$ aminobutyric acid type A receptors, including an epilepsy-linked mutant variant." Biochemistry 49.23 (2010): 4841-4851. https://doi.org/10.1021/bi100119t

29. Patil, Ashok D., et al. "Novel alkaloids from the sponge Batzella sp.: inhibitors of HIV gp120human CD4 binding." The Journal of Organic Chemistry 60.5 (1995): 1182-1188. https://doi.org/10.1021/jo00110a021

30. Figueroa-Valverde, Lauro, et al. "Activity induced by two Steroid-Dihydropyrimidine derivatives on Glucose levels in a Diabetic Rat Model. Relationship between descriptors $\log P$ and $\pi$ and its Antidiabetic activity." International Journal of PharmTech Research (2010): 2075-2080.

31. Patel, Ashish D., et al. "Molecular Docking, In-Silico ADMET Study and Development of 1, 6Dihydropyrimidine Derivative as Protein Tyrosine Phosphatase Inhibitor: An Approach to Design and Develop Antidiabetic Agents." Current Computer-Aided Drug Design 14.4 (2018): 349-362. https://doi.org/10.2174/1573409914666180426125721

32. Mehtaa, Krishna B., and Rajesh K. Patelb Hitendra S. Joshic. "In silico study of novel Dihydropyrimidines against Anti Cancer, Anti Tuberculosis, Anti HIV and Anti Malarial activity." Int. J. Scient. Eng. Res 4 (2013): 1-8.

33. Terracciano, Stefania, et al. "Structural insights for the optimization of dihydropyrimidin-2 (1 H)-one based mPGES-1 inhibitors." ACS medicinal chemistry letters 6.2 (2015): 187-191. https://doi.org/10.1021/m1500433j

34. Trivedi, Amit R., et al. "Novel dihydropyrimidines as a potential new class of antitubercular agents." Bioorganic \& medicinal chemistry letters 20.20 (2010): 6100-6102. https://doi.org/10.1016/j.bmcl.2010.08.046

35. Singh, Brajesh K., et al. "Synthesis of 2-sulfanyl-6-methyl-1, 4-dihydropyrimidines as a new class of antifilarial agents." European journal of medicinal chemistry 43.12 (2008): 2717-2723. https://doi.org/10.1016/j.ejmech.2008.01.038

36. Barrow, James C., et al. "In vitro and in vivo evaluation of dihydropyrimidinone C-5 amides as potent and selective $\alpha 1 \mathrm{~A}$ receptor antagonists for the treatment of benign prostatic hyperplasia." Journal of medicinal chemistry 43.14 (2000): 2703-2718. https://doi.org/10.1021/jm990612y

37. Zhu, Xuejun, et al. "2, 4-Diaryl-4, 6, 7, 8-tetrahydroquinazolin-5 (1H)-one derivatives as antiHBV agents targeting at capsid assembly." Bioorganic \& medicinal chemistry letters 20.1 (2010): 299-301. https://doi.org/10.1016/j.bmcl.2009.10.119

38. G.C. Rovnyak, K.S. Atwal, A. Hedberg, S.D. Kimball, S. Moreland, J.Z. Gougoutas, B.C. O'Reilly, J. Schwartz, M.F. Malley. "Dihydropyrimidine calcium channel blockers. 4. Basic 3substituted-4-aryl-1,4-dihydropyrimidine-5-carboxylic acid esters. Potent antihypertensive agents", J. Med. Chem. 35 (17) (1992) 3254-3263, http://dx.doi.org/10.1021/jm00095a023.

39. Finlay, H. J., Lloyd, J., Vaccaro, W., Kover, A., Yan, L., Bhave, G., ... \& DiMarco, J. (2012). Discovery of ((S)-5-(Methoxymethyl)-7-(1-methyl-1 H-indol-2-yl)-2-(trifluoromethyl)-4, 7dihydropyrazolo $[1,5-a]$ pyrimidin-6-yl)((S)-2-(3-methylisoxazol-5-yl) pyrrolidin-1-yl) 
methanone As a Potent and Selective IKur Inhibitor. Journal of medicinal chemistry, 55(7), 3036-3048. https://doi.org/10.1021/jm201386u

40. Lloyd, John, et al. "Pyrrolidine amides of pyrazolodihydropyrimidines as potent and selective KV1. 5 blockers." Bioorganic \& medicinal chemistry letters 20.4 (2010): 1436-1439. https://doi.org/10.1016/j.bmcl.2009.12.085

41. Lloyd, John, et al. "Dihydropyrazolopyrimidines containing benzimidazoles as KV1. 5 potassium channel antagonists." Bioorganic \& medicinal chemistry letters 19.18 (2009): 5469-5473. https://doi.org/10.1016/j.bmcl.2009.07.083

42. Wong, Wai C., et al. "Design and Synthesis of Novel $\alpha$ la Adrenoceptor-Selective Antagonists. 4. Structure- Activity Relationship in the Dihydropyrimidine Series." Journal of medicinal chemistry 42.23 (1999): 4804-4813. https://doi.org/10.1021/jm9902032

43. Devadasu, Venkat Ratnam, et al. "Physicochemical, Pharmaceutical, and Biological Considerations in GIT Absorption of Drugs." Dosage Form Design Considerations. Academic Press, 2018. 149-178. https://doi.org/10.1016/B978-0-12-814423-7.00005-8

44. Pandey, Vikas, et al. "Formulation strategies for nose-to-brain delivery of therapeutic molecules." Drug Delivery Systems. Academic Press, 2020. 291-332. https://doi.org/10.1016/B978-0-12-8144879.00007-7

45. Morozowich, Walt, and Ping Gao. "Improving the oral absorption of poorly soluble drugs using SEDDS and S-SEDDS formulations." Developing Solid Oral Dosage Forms. Academic Press, 2009. 443-468. https://doi.org/10.1016/B978-0-444-53242-8.00019-9

46. Kaur, R., Chaudhary, S., Kumar, K., Gupta, M. K., \& Rawal, R. K. (2017). Recent synthetic and medicinal perspectives of dihydropyrimidinones: A review. European journal of medicinal chemistry, 132, 108-134. https://doi.org/10.1016/j.ejmech.2017.03.025

47. A.C. Boukis, A. Llevot, M.A.R. Meier. "High glass transition temperature renewable polymers via Biginelli multicomponent polymerization”, Macromol. Rapid Commun. 2016, 37, 643. https://doi.org/10.1002/marc.201500717

48. S.R. Patil, A.S. Choudhary, V.S. Patil, N. Sekar. "Synthesis, optical properties, dyeing study of dihydropyrimidones (DHPMs) skeleton: Green and regioselectivity of novel Biginelli scaffold from lawsone", Fibers and Polym. 2015, 16, 2349. https://doi.org/10.1007/s12221-015-5233-x

49. Gholap, A. R., Toti, K. S., Shirazi, F., Deshpande, M. V., \& Srinivasan, K. V. (2008). Efficient synthesis of antifungal pyrimidines via palladium catalyzed Suzuki/Sonogashira cross-coupling reaction from Biginelli 3, 4-dihydropyrimidin-2 (1H)-ones. Tetrahedron, 64(44), 10214-10223. https://doi.org/10.1016/j.tet.2008.08.033

50. Shanmugam, P., \& Perumal, P. T. (2006). Regioselective dehydrogenation of 3, 4dihydropyrimidin-2 (1H)-ones mediated by ceric ammonium nitrate. Tetrahedron, 62(41), 97269734. https://doi.org/10.1016/j.tet.2006.07.063

51. Yamamoto, K., Chen, Y. G., \& Buono, F. G. (2005). Oxidative dehydrogenation of dihydropyrimidinones and dihydropyrimidines. Organic letters, 7(21), 4673-4676. https://doi.org/10.1021/o1051879w 
52. Hayashi, M., Okunaga, K. I., Nishida, S., Kawamura, K., \& Eda, K. (2010). Oxidative transformation of thiols to disulfides promoted by activated carbon-air system. Tetrahedron Letters, 51(51), 6734-6736. https://doi.org/10.1016/j.tetlet.2010.10.070

53. GM. Sheldrick. SHELXTL V5.1, Software reference manual. Madison, Wisconsin: Bruker AXS Inc.; 1997, 1-250.

54. Guillot, B., Enrique, E., Huder, L., \& Jelsch, C. (2014). MS19. O01. Acta Cryst, 70, C279.

55. Domagała, S., Fournier, B., Liebschner, D., Guillot, B., \& Jelsch, C. (2012). An improved experimental databank of transferable multipolar atom models-ELMAM2. Construction details and applications. Acta Crystallographica Section A: Foundations of Crystallography, 68(3), 337-351. https://doi.org/10.1107/S0108767312008197

56. Allen, F. H., \& Bruno, I. J. (2010). Bond lengths in organic and metal-organic compounds revisited: $\mathrm{X}-\mathrm{H}$ bond lengths from neutron diffraction data. Acta Crystallographica Section B: Structural Science, 66(3), 380-386. https://doi.org/10.1107/S0108768110012048

57. Jelsch, C., Guillot, B., Lagoutte, A., \& Lecomte, C. (2005). Advances in protein and small-molecule charge-density refinement methods using MoPro. Journal of applied crystallography, 38(1), 38-54. https://doi.org/10.1107/S0021889804025518

58. A. Martin, H. Takiff, P. Vandamme, J. Swings, J.C. Palomino and F. Portaels. "A new rapid and simple colorimetric method to detect pyrazinamide resistance in Mycobacterium tuberculosis using nicotinamide". J.Antimicrob Chem other., 2006, 58, 327-331. doi:10.1093/jac/dk1231

59. Mayrhofer, Sigrid, et al. "Comparison of broth microdilution, Etest, and agar disk diffusion methods for antimicrobial susceptibility testing of Lactobacillus acidophilus group members." Appl. Environ. Microbiol. 74.12 (2008): 3745-3748. DOI: 10.1128/AEM.02849-07

60. Wu, M., Yu, J., Zhao, W., Wu, J., \& Cao, S. (2011). One-pot synthesis of difluoromethylcontaining dihydropyrimidinones catalyzed by $\mathrm{Yb}$ (PFO) 3 under solvent and dehydrating agent free conditions. Journal of Fluorine Chemistry, 132(3), 155-159. https://doi.org/10.1016/j.jfluchem.2010.12.010

61. Prajapati, D., Bhuyan, D., Gohain, M., \& Hu, W. (2011). Green chemistry approaches to the regioselective synthesis of spiro heterobicyclic rings using iodine as a new and efficient catalyst under solvent-free conditions. Molecular diversity, 15(1), 257-261. https://doi.org/10.1007/s11030-010-9247-4

62. Srivastava, V. P., \& Yadav, L. D. S. (2010). Biginelli reaction starting directly from alcohols. Tetrahedron Letters, 51(49), 6436-6438. https://doi.org/10.1016/j.tetlet.2010.09.141

63. Wan, J. P., Wang, C., \& Pan, Y. (2011). Novel four-component reaction towards diastereoselective synthesis of tetrahydropyrimidinthiones. Tetrahedron, 67(5), 922-926. https://doi.org/10.1016/j.tet.2010.12.011

64. Gupta, P., Gupta, S., Sachar, A., Kour, D., Singh, J., \& Sharma, R. L. (2010). One pot synthesis of spiro pyrimidinethiones/spiro pyrimidinones, quinazolinethiones/quinazolinones, and pyrimidopyrimidines. Journal of Heterocyclic Chemistry, 47(2), 324-333. https://doi.org/10.1002/jhet.282 
65. Sadek, K. U., Al-Qalaf, F., Abdelkhalik, M. M., \& Elnagdi, M. H. (2010). Cerium (IV) ammonium nitrate as an efficient Lewis acid for the one-pot synthesis of 3, 4-dihydropyrimidin$2(1 \mathrm{H})$-ones and their corresponding 2-(1H) thiones. Journal of Heterocyclic Chemistry, 47(2), 284. DOI 10.1002/jhet

66. Liu, C. J., \& Wang, J. D. (2010). Ultrasound-assisted synthesis of novel 4-(2-phenyl-1, 2, 3triazol-4-yl)-3, 4-dihydropyrimidin-2 (1H)-(thio) ones catalyzed by $\mathrm{Sm}(\mathrm{ClO} 4)$ 3. Molecules, 15(4), 2087-2095. https://doi.org/10.3390/molecules15042087

67. Matache, M., Dobrota, C., Bogdan, N. D., Dumitru, I., Ruta, L. L., Paraschivescu, C. C., ... \& Funeriu, D. P. (2009). Synthesis of fused dihydro-pyrimido [4, 3-d] coumarins using Biginelli multicomponent reaction as key step. Tetrahedron, 65(31), 5949-5957. https://doi.org/10.1016/j.tet.2009.05.088

68. De, S. K., \& Gibbs, R. A. (2005). Ruthenium (III) chloride-catalyzed one-pot synthesis of 3, 4dihydropyrimidin-2-(1H)-ones under solvent-free conditions. Synthesis, 2005(11), 1748-1750. DOI: $10.1055 / \mathrm{s}-2005-86989$

69. Kamble, V. T., Muley, D. B., Atkore, S. T., \& Dakore, S. D. (2010). Three Component Reaction: An Efficient Synthesis of 3, 4-Dihydropyrimidin-2 (1H)-ones and Thiones Using Heterogeneous Catalyst. Chinese Journal of Chemistry, 28(3), 388-392. https://doi.org/10.1002/cjoc.201090084

70. Pourghobadi, Z., \& Derikvand, F. (2010). H3PMo12O40 catalyzed three-component one-pot synthesis of 4, 6-diarylpyrimidin-2 $(1 \mathrm{H})$-ones under solvent-free conditions. Chinese Chemical Letters, 21(3), 269-272. https://doi.org/10.1016/j.cclet.2009.11.003

71. De, S. K., \& Gibbs, R. A. (2005). Scandium (III) Triflate as an Efficient and Reusable Catalyst for Synthesis of 3, 4-Dihydropyrimidin-2 (1H)-ones. Synthetic communications, 35(20), 26452651. https://doi.org/10.1080/00397910500213781

72. Zhang, G. L., \& Cai, X. H. (2005). Magnesium Chloride Hexahydrate Catalyzed One-Pot Synthesis of 3, 4-Dihydropyrimidin-2-(1 H) ones Under Solvent-Free Conditions. Synthetic communications, 35(6), 829-833. https://doi.org/10.1081/SCC-200050956

73. Godoi, M. N.; Costenaro, H. S.; Kramer, E.; Machado, P. S.; Doca, M. G. M.; Russowsky, D. Quim. Nova 2005, 28, 1010.

74. Pasunooti, K. K., Chai, H., Jensen, C. N., Gorityala, B. K., Wang, S., \& Liu, X. W. (2011). A microwave-assisted, copper-catalyzed three-component synthesis of dihydropyrimidinones under mild conditions. Tetrahedron Letters, 52(1), 80-84. https://doi.org/10.1016/j.tetlet.2010.10.150

75. Huseynzada, A. E., Jelsch, C., Akhundzada, H. N., Soudani, S., Nasr, C. B., Doria, F., ... \& Freccero, M. (2020). Synthesis, crystal structure and antibacterial properties of 6-methyl-2-oxo-4-(quinolin-2yl)-1, 2, 3, 4-tetrahydropyrimidine-5-carboxylate. Journal of Molecular Structure, 128581. https://doi.org/10.1016/j.molstruc.2020.128581

76. Nayak, S. K., Venugopala, K. N., Chopra, D., \& Row, T. G. (2010). Effect of substitution on molecular conformation and packing features in a series of aryl substituted ethyl-6-methyl-4-phenyl-2-thioxo-1, 2, 3, 4-tetrahydropyrimidine-5-carboxylates. CrystEngComm, 12(4), 1205-1216. DOI: $10.1039 / \mathrm{B} 919648 \mathrm{~J}$ 
77. Kappe, C. O., Shishkin, O. V., Uray, G., \& Verdino, P. (2000). X-ray structure, conformational analysis, enantioseparation, and determination of absolute configuration of the mitotic kinesin Eg5 inhibitor monastrol. Tetrahedron, 56(13), 1859-1862. https://doi.org/10.1016/S0040-4020(00)00116$\underline{2}$

78. Jelsch, C., Ejsmont, K., \& Huder, L. (2014). The enrichment ratio of atomic contacts in crystals, an indicator derived from the Hirshfeld surface analysis.IUCrJ, 1(2), 119-128. https://doi.org/10.1107/S2052252514003327

79. Jelsch, C., Soudani, S., \& Ben Nasr, C. (2015). Likelihood of atom-atom contacts in crystal structures of halogenated organic compounds. IUCrJ, 2(3), 327-340. https://doi.org/10.1107/S2052252515003255

80. Etter, M. C. (1991). Hydrogen bonds as design elements in organic chemistry. The Journal of Physical Chemistry, 95(12), 4601-4610. https://doi.org/10.1021/j100165a007 


\section{Supplementary Materials}

\section{Table of contents}

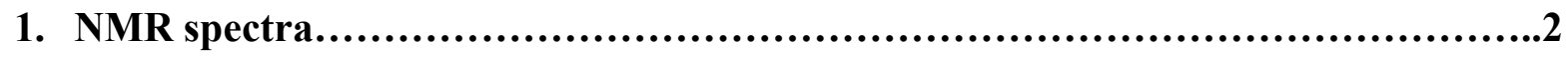

2. MS spectra..........................................................................5

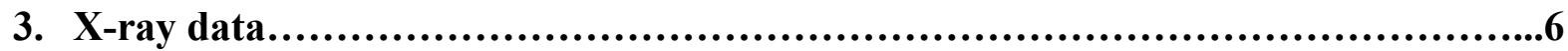

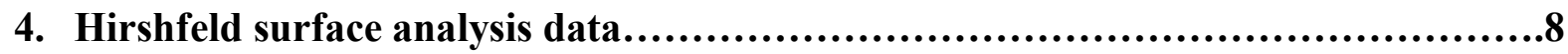


Table S1. Selected bond lengths $(\AA)$ and bond angles $\left(^{\circ}\right)$ for non-H atoms with esd values in parenthesis for the title compound.

\begin{tabular}{|c|c|c|c|}
\hline $\mathrm{O} 1-\mathrm{C} 7$ & $1.2239(18)$ & $\mathrm{C} 1-\mathrm{C} 6$ & $1.3560(18)$ \\
\hline $\mathrm{O} 2-\mathrm{C} 4$ & $1.2368(16)$ & $\mathrm{C} 1-\mathrm{C} 7$ & $1.4725(18)$ \\
\hline $\mathrm{O} 3-\mathrm{C} 11$ & $1.3631(17)$ & $\mathrm{C} 1-\mathrm{C} 2$ & $1.5285(17)$ \\
\hline $\mathrm{O} 3-\mathrm{C} 16$ & $1.4066(19)$ & $\mathrm{C} 10-\mathrm{C} 15$ & $1.3920(19)$ \\
\hline $\mathrm{O} 4-\mathrm{C} 13$ & $1.3715(18)$ & $\mathrm{C} 10-\mathrm{C} 11$ & $1.4049(18)$ \\
\hline $\mathrm{O} 4-\mathrm{C} 17$ & $1.421(2)$ & $\mathrm{C} 11-\mathrm{C} 12$ & $1.390(2)$ \\
\hline $\mathrm{O} 5-\mathrm{C} 15$ & $1.3664(16)$ & $\mathrm{C} 12-\mathrm{C} 13$ & $1.389(2)$ \\
\hline $\mathrm{O} 5-\mathrm{C} 18$ & $1.414(2)$ & $\mathrm{C} 2-\mathrm{C} 10$ & $1.5254(17)$ \\
\hline $\mathrm{N} 3-\mathrm{C} 4$ & $1.3383(17)$ & $\mathrm{C} 6-\mathrm{C} 9$ & $1.5007(18)$ \\
\hline $\mathrm{N} 3-\mathrm{C} 2$ & $1.4725(16)$ & $\mathrm{C} 7-\mathrm{C} 8$ & $1.505(2)$ \\
\hline $\mathrm{N} 5-\mathrm{C} 4$ & $1.3727(16)$ & $\mathrm{C} 13-\mathrm{C} 14$ & $1.383(2)$ \\
\hline N5-C6 & $1.3754(17)$ & $\mathrm{C} 14-\mathrm{C} 15$ & $1.399(2)$ \\
\hline $\mathrm{C} 11-\mathrm{O} 3-\mathrm{C} 16$ & $119.15(13)$ & $\mathrm{O} 1-\mathrm{C} 7-\mathrm{C} 1$ & $122.74(13)$ \\
\hline $\mathrm{C} 13-\mathrm{O} 4-\mathrm{C} 17$ & $118.41(14)$ & $\mathrm{O} 1-\mathrm{C} 7-\mathrm{C} 8$ & $117.64(13)$ \\
\hline $\mathrm{C} 15-\mathrm{O} 5-\mathrm{C} 18$ & $119.08(13)$ & $\mathrm{O} 2-\mathrm{C} 4-\mathrm{N} 3$ & $123.67(12)$ \\
\hline $\mathrm{C} 4-\mathrm{N} 3-\mathrm{C} 2$ & $125.92(11)$ & $\mathrm{O} 2-\mathrm{C} 4-\mathrm{N} 5$ & $119.97(12)$ \\
\hline $\mathrm{C} 4-\mathrm{N} 5-\mathrm{C} 6$ & $124.03(11)$ & $\mathrm{O} 3-\mathrm{C} 11-\mathrm{C} 12$ & $122.75(12)$ \\
\hline $\mathrm{C} 4-\mathrm{N} 5-\mathrm{H} 5$ & $114.7(13)$ & $\mathrm{O} 3-\mathrm{C} 11-\mathrm{C} 10$ & $115.63(12)$ \\
\hline $\mathrm{C} 6-\mathrm{N} 5-\mathrm{H} 5$ & $120.3(13)$ & $\mathrm{O} 4-\mathrm{C} 13-\mathrm{C} 14$ & $124.02(15)$ \\
\hline $\mathrm{N} 3-\mathrm{C} 4-\mathrm{N} 5$ & $116.30(12)$ & $\mathrm{O} 4-\mathrm{C} 13-\mathrm{C} 12$ & $114.59(14)$ \\
\hline $\mathrm{N} 5-\mathrm{C} 6-\mathrm{C} 9$ & $112.49(11)$ & $\mathrm{O} 5-\mathrm{C} 15-\mathrm{C} 10$ & $115.01(12)$ \\
\hline $\mathrm{N} 3-\mathrm{C} 2-\mathrm{C} 10$ & $110.27(10)$ & $\mathrm{O} 5-\mathrm{C} 15-\mathrm{C} 14$ & $122.59(13)$ \\
\hline $\mathrm{N} 3-\mathrm{C} 2-\mathrm{C} 1$ & $110.64(10)$ & $\mathrm{C} 10-\mathrm{C} 15-\mathrm{C} 14$ & $122.39(12)$ \\
\hline $\mathrm{C} 1-\mathrm{C} 7-\mathrm{C} 8$ & $119.61(12)$ & $\mathrm{C} 11-\mathrm{C} 10-\mathrm{C} 2$ & $120.13(11)$ \\
\hline $\mathrm{C} 1-\mathrm{C} 6-\mathrm{N} 5$ & $120.85(11)$ & $\mathrm{C} 12-\mathrm{C} 11-\mathrm{C} 10$ & $121.62(13)$ \\
\hline $\mathrm{C} 1-\mathrm{C} 6-\mathrm{C} 9$ & $126.65(12)$ & $\mathrm{C} 13-\mathrm{C} 12-\mathrm{C} 11$ & $119.04(13)$ \\
\hline $\mathrm{C} 6-\mathrm{C} 1-\mathrm{C} 7$ & $121.09(11)$ & $\mathrm{C} 14-\mathrm{C} 13-\mathrm{C} 12$ & $121.40(13)$ \\
\hline $\mathrm{C} 6-\mathrm{C} 1-\mathrm{C} 2$ & $119.83(11)$ & $\mathrm{C} 13-\mathrm{C} 14-\mathrm{C} 15$ & $118.30(13)$ \\
\hline $\mathrm{C} 7-\mathrm{C} 1-\mathrm{C} 2$ & $119.07(11)$ & $\mathrm{C} 15-\mathrm{C} 10-\mathrm{C} 11$ & $117.19(12)$ \\
\hline $\mathrm{C} 10-\mathrm{C} 2-\mathrm{C} 1$ & $114.90(10)$ & $\mathrm{C} 15-\mathrm{C} 10-\mathrm{C} 2$ & $122.62(11)$ \\
\hline
\end{tabular}

Table S2. Geometric details of hydrogen bonds $\left(\AA,^{\circ}\right)$ (D-donor; A-acceptor; H-hydrogen).

\begin{tabular}{|l|l|l|l|l|}
\hline $\mathrm{D}-\mathrm{H} \cdots \mathrm{A}$ & $\mathrm{D}-\mathrm{H}$ & $\mathrm{H} \cdots \mathrm{A}$ & $\mathrm{D} \cdots \mathrm{A}$ & $\mathrm{D}-\mathrm{H} \cdots \mathrm{A}$ \\
\hline $\mathrm{N} 3-\mathrm{H} 3 \cdots \mathrm{O} 1^{\mathrm{i}}$ & 0.92 & 2.16 & $3.061(2)$ & 169 \\
\hline $\mathrm{N} 5-\mathrm{H} 5 \cdots \mathrm{O} 2^{\mathrm{ii}}$ & 0.89 & 1.99 & $2.873(2)$ & 175 \\
\hline $\mathrm{C} 2-\mathrm{H} 2 \mathrm{~A} \cdots \mathrm{O} 3$ & 0.98 & 2.25 & $2.761(2)$ & 111 \\
\hline $\mathrm{C} 8-\mathrm{H} 8 \mathrm{~A} \cdots \mathrm{O} 3$ & 0.96 & 2.40 & $3.344(3)$ & 167 \\
\hline $\mathrm{C} 9-\mathrm{H} 9 \mathrm{~B} \cdots \mathrm{O} 22^{\text {iii }}$ & 0.96 & 2.52 & $3.127(2)$ & 121 \\
\hline
\end{tabular}

Symmetry codes : (i) $\mathrm{x}+1, \mathrm{y}, \mathrm{z}$; (ii) $-\mathrm{x}+1,-\mathrm{y},-\mathrm{z}$; (iii) $\mathrm{x}-1, \mathrm{y}, \mathrm{z}$ 


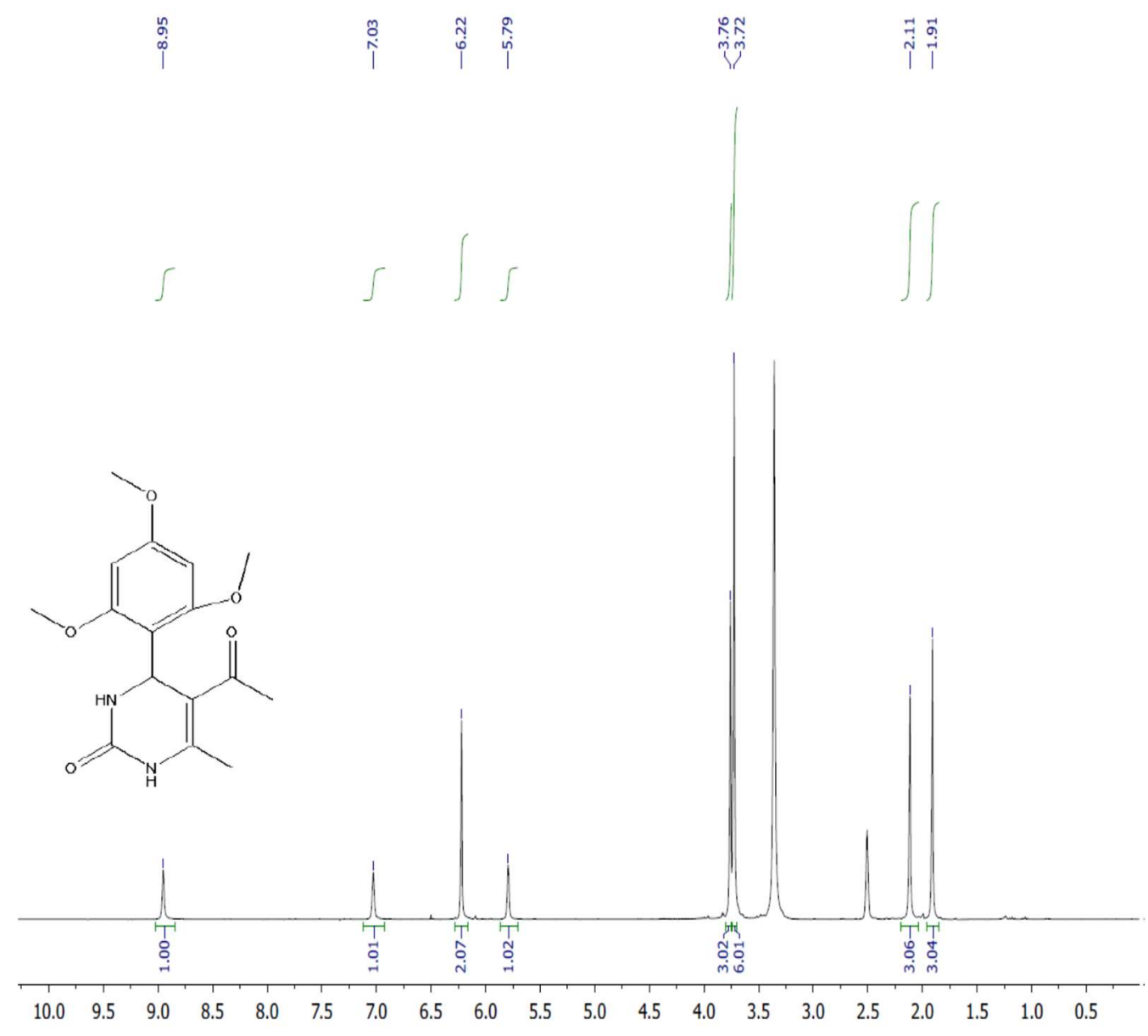

Figure S1. ${ }^{1} \mathrm{H}$ NMR spectrum of synthesized dihydropyrimidine 4

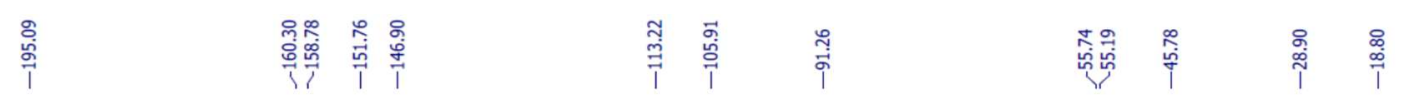<smiles>COc1cc(OC)c(C2NC(=O)NC(C)=C2C(C)=O)c(OC)c1</smiles>

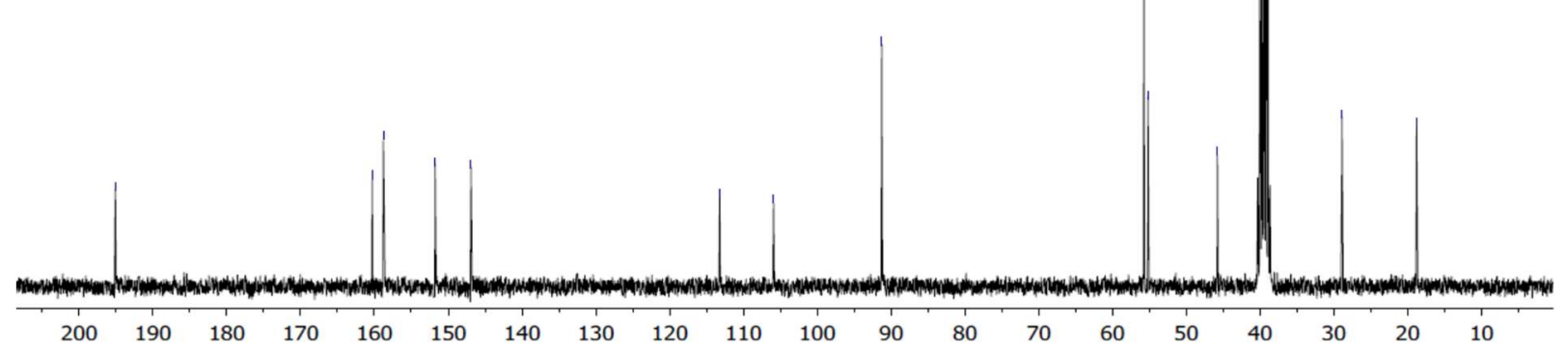

Figure S2. ${ }^{13} \mathrm{C}$ NMR spectrum of synthesized dihydropyrimidine 4 


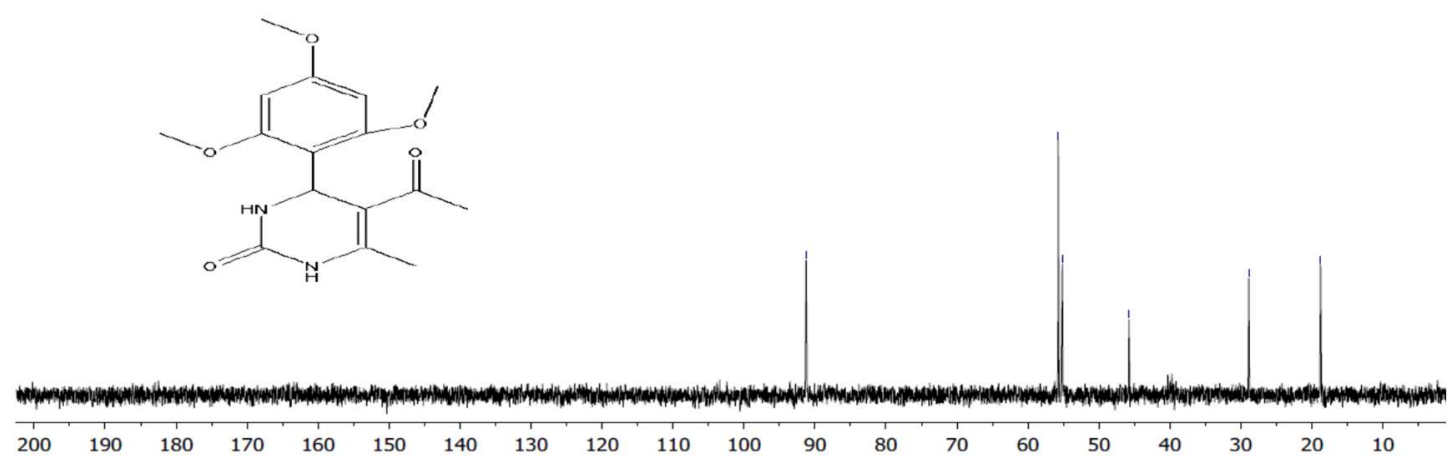

Figure S3. dept135 NMR spectrum of synthesized dihydropyrimidine 4

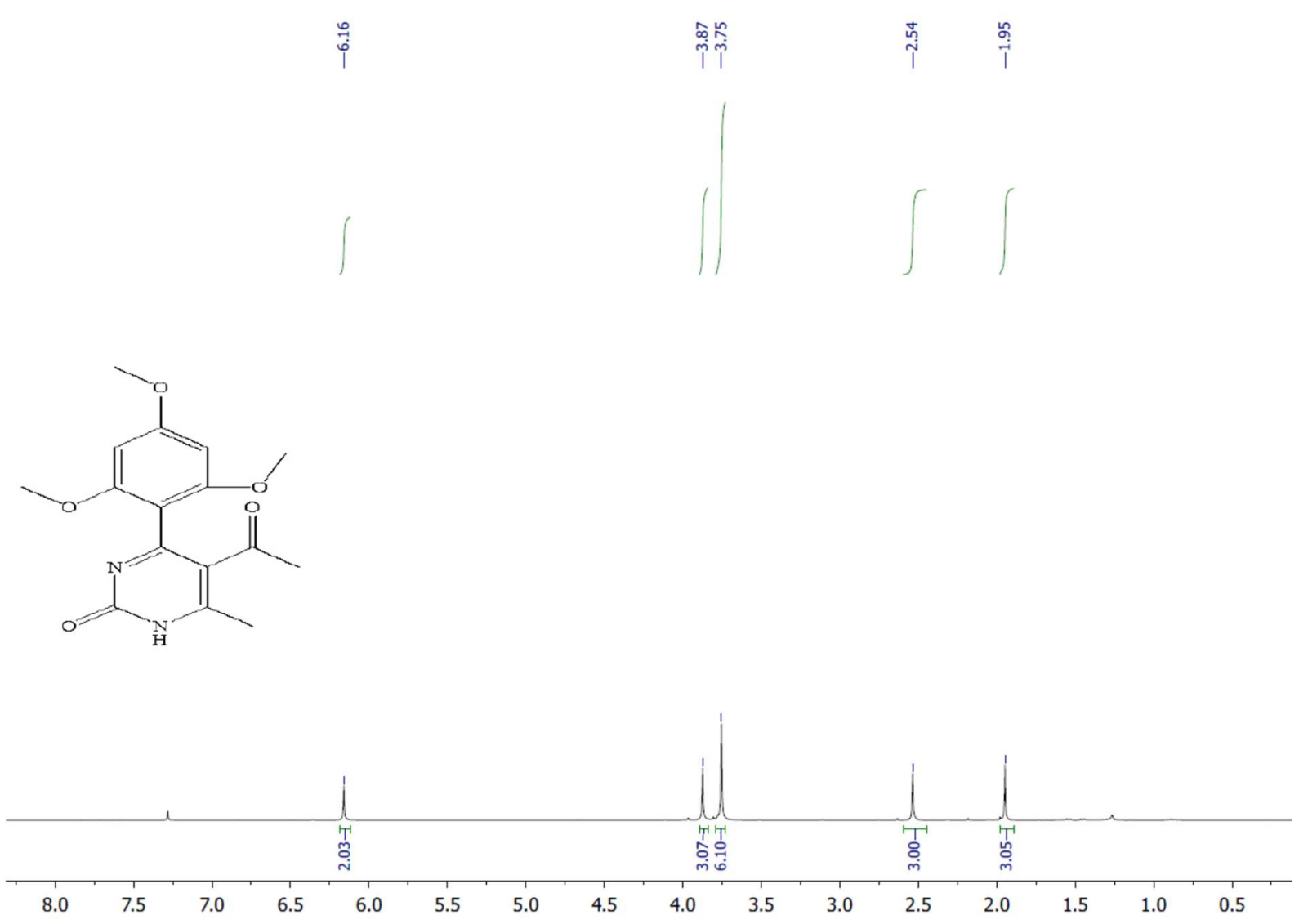

Figure S4. ${ }^{1} \mathrm{H}$ NMR spectrum of synthesized dihydropyrimidine 5 


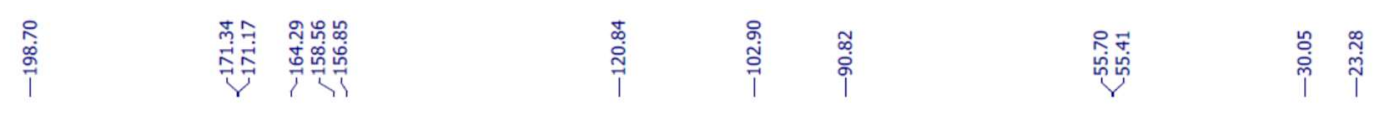<smiles>COc1cc(OC)c(-c2nc(=O)[nH]c(C)c2C(C)=O)c(OC)c1</smiles>

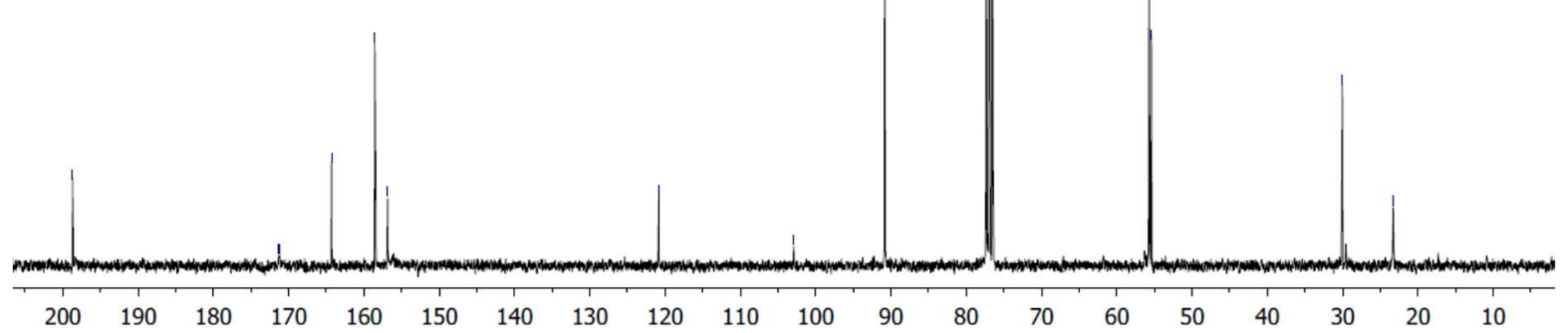

Figure S5. ${ }^{13} \mathrm{C}$ NMR spectrum of synthesized dihydropyrimidine 5

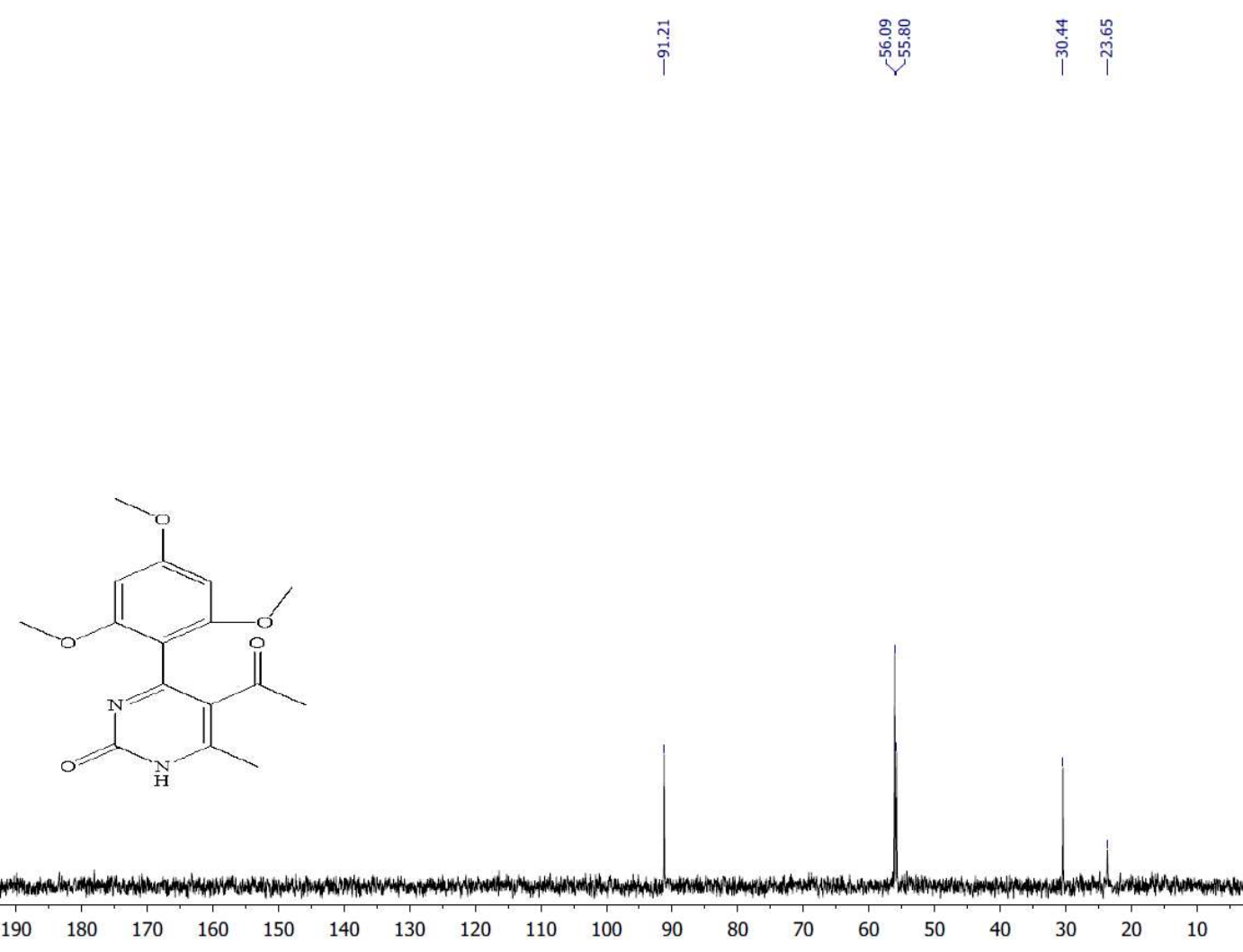

Figure S6. dept135 NMR spectrum of synthesized dihydropyrimidine 5 


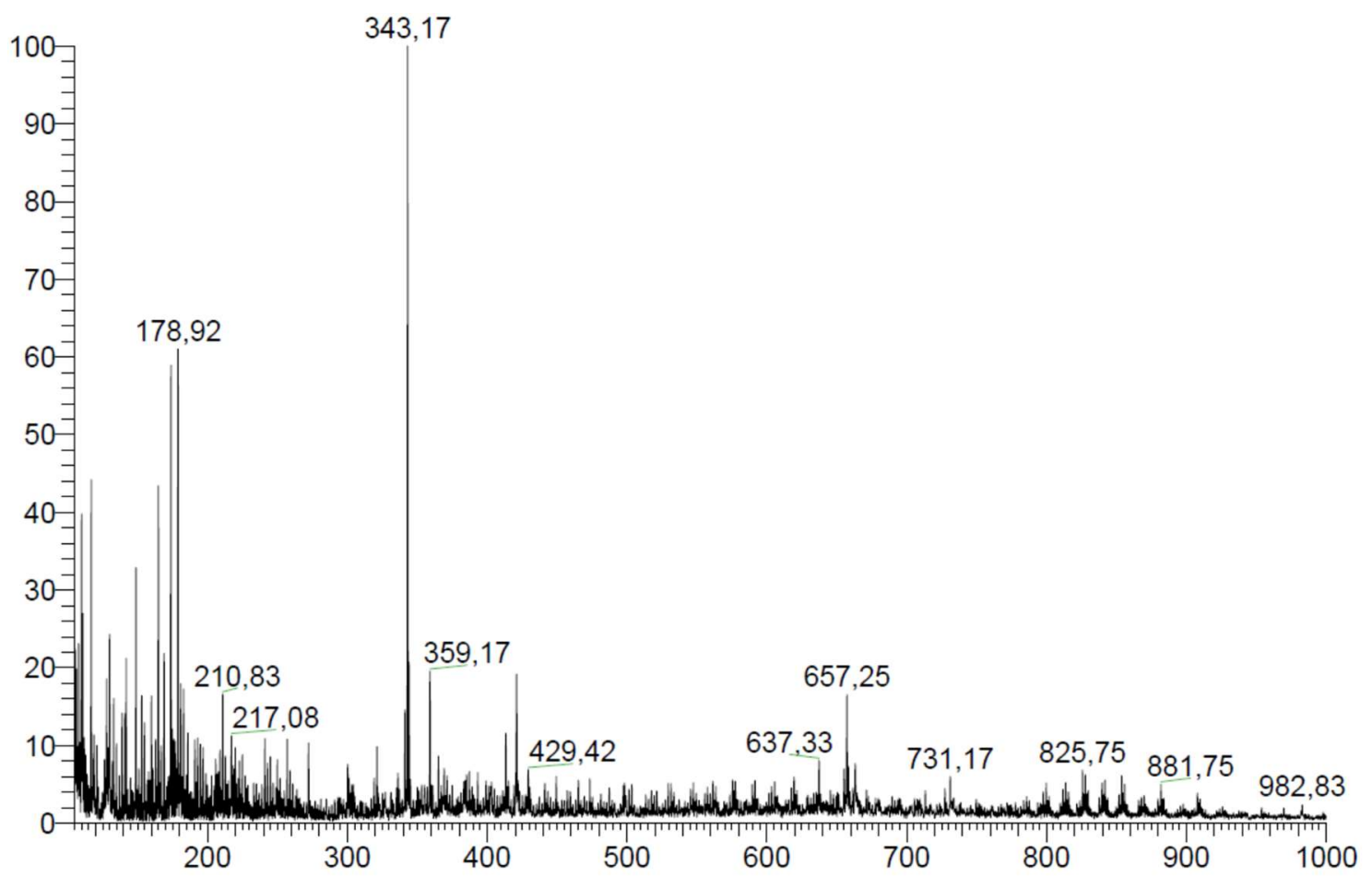

Figure S7. MS spectrum of synthesized dihydropyrimidine 4

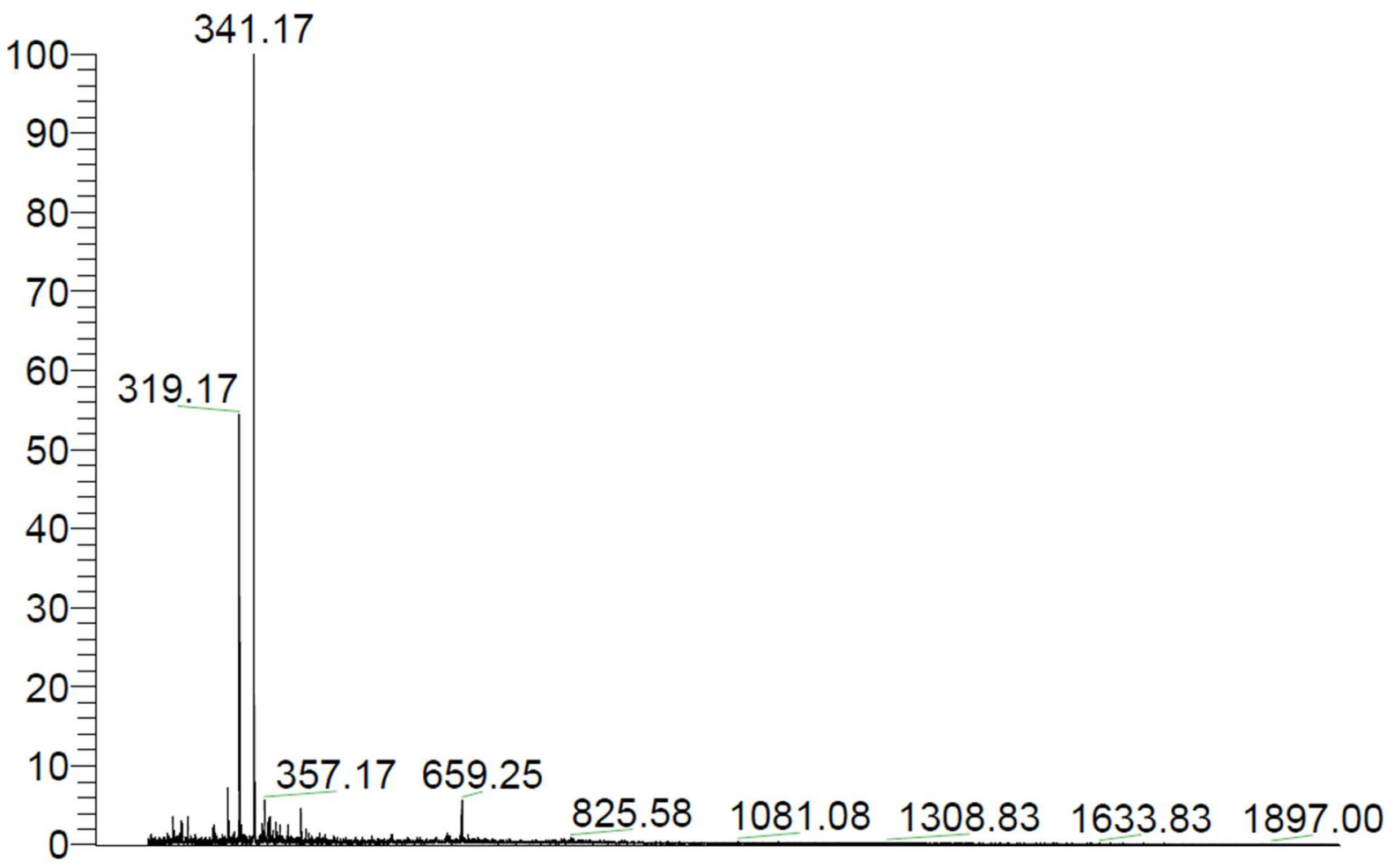

Figure S8. MS spectrum of synthesized dihydropyrimidine 5 

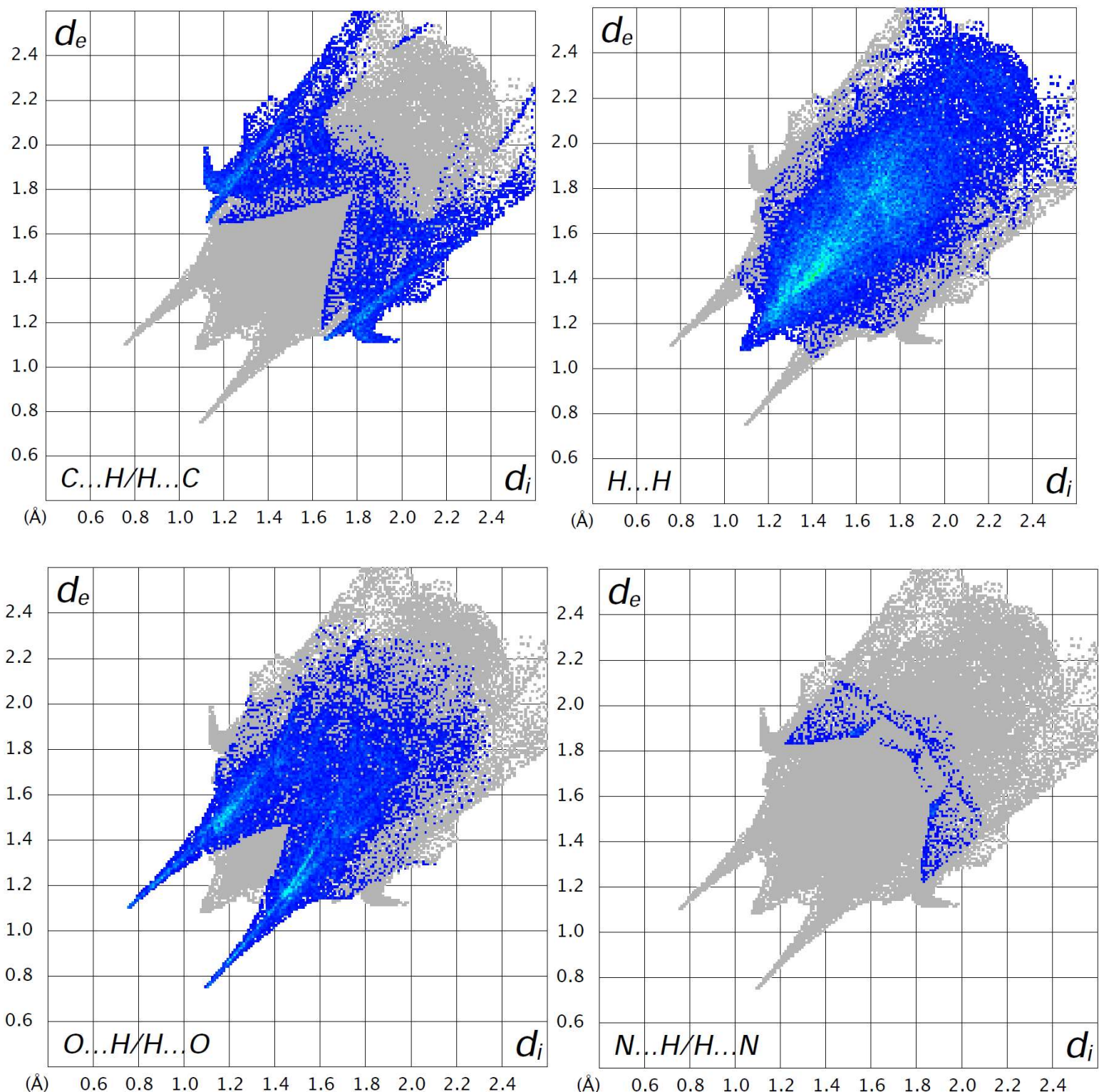

Figure S9. Fingerprint plot of the main contacts at the Hirshfeld surface computed with program Crystal Explorer 17 [1].

1. McKinnon, J. J., Jayatilaka, D., \& Spackman, M. A. (2007). Towards quantitative analysis of intermolecular interactions with Hirshfeld surfaces. Chemical Communications, (37), 3814-3816. DOI: 10.1039/B704980C 


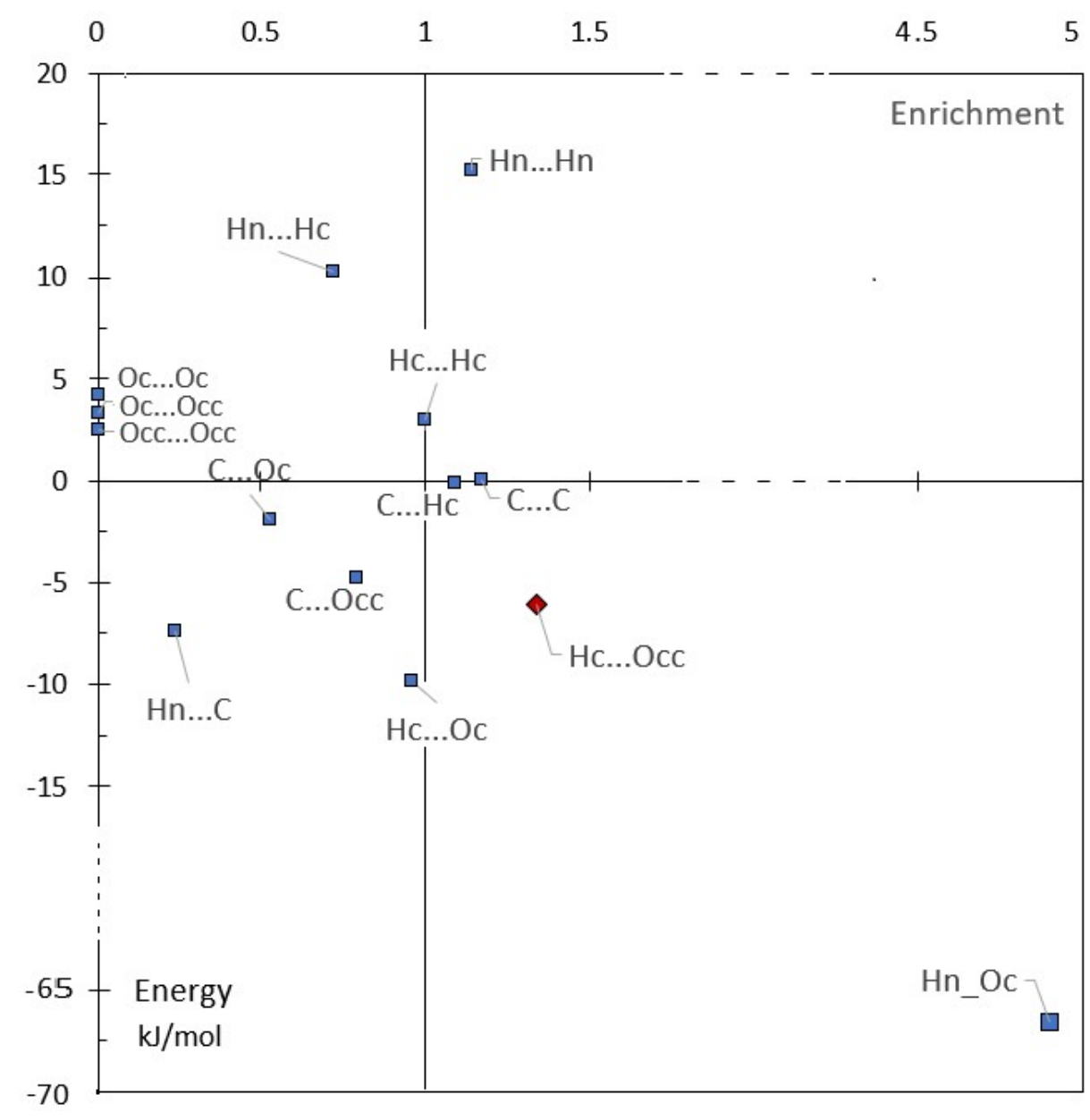

Figure S10.

Scatterplot of contacts enrichment and average electrostatic energy per contact type 